
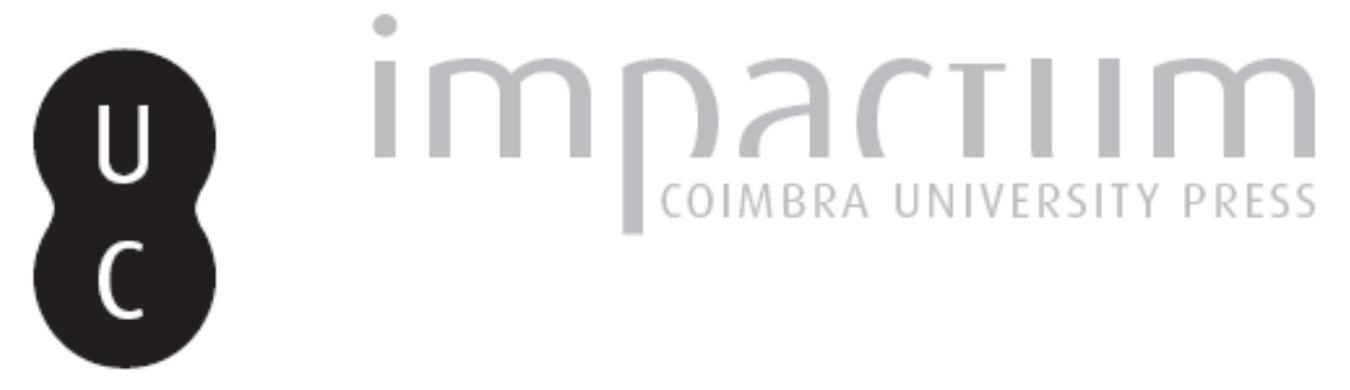

\title{
À conquista da sabedoria: a pintura de quadratura e o programa iconográfico da
} Biblioteca Joanina

Autor(es): Raggi, Giuseppina

Publicado por: Imprensa da Universidade de Coimbra

URL persistente:

URI:http://hdl.handle.net/10316.2/45019

DOI:

DOI:https://doi.org/10.14195/1647-8436_48_2

Accessed : $\quad$ 18-Feb-2019 15:10:20

A navegação consulta e descarregamento dos títulos inseridos nas Bibliotecas Digitais UC Digitalis, UC Pombalina e UC Impactum, pressupõem a aceitação plena e sem reservas dos Termos e Condições de Uso destas Bibliotecas Digitais, disponíveis em https://digitalis.uc.pt/pt-pt/termos.

Conforme exposto nos referidos Termos e Condições de Uso, o descarregamento de títulos de acesso restrito requer uma licença válida de autorização devendo o utilizador aceder ao(s) documento(s) a partir de um endereço de IP da instituição detentora da supramencionada licença.

Ao utilizador é apenas permitido o descarregamento para uso pessoal, pelo que o emprego do(s) título(s) descarregado(s) para outro fim, designadamente comercial, carece de autorização do respetivo autor ou editor da obra.

Na medida em que todas as obras da UC Digitalis se encontram protegidas pelo Código do Direito de Autor e Direitos Conexos e demais legislação aplicável, toda a cópia, parcial ou total, deste documento, nos casos em que é legalmente admitida, deverá conter ou fazer-se acompanhar por este aviso.

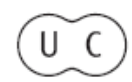




\section{BOLETIM DA \\ BIBLIOTECA GERAL DA UNIVERSIDADE DE COIMBRA}

VOL. 48 (2018)

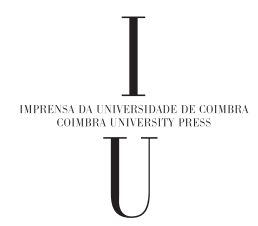




\section{À conquista da sabedoria. A pintura de quadratura e o programa iconográfico da Biblioteca Joanina}

Giuseppina Raggi ${ }^{1}$

\section{RESUMO}

O artigo propõe a releitura do processo de construção e decoração da Biblioteca da Universidade de Coimbra, conhecida como Biblioteca Joanina (1716-1728). O texto reinterpreta o contexto artístico e cultural da primeira metade do reinado de D. João V (1707- acerca de 1728) e o impacto dos projetos do arquiteto italiano Filippo Juvarra para a nova cidade de Lisboa (1719). A construção da Biblioteca Joanina integrou o plano de renovação do conhecimento em todos os campos do saber promovido por D. João V, pela rainha D. Maria Ana de Áustria e pela corte portuguesa. Desta forma, o artigo oferece uma nova interpretação do programa iconográfico, baseado na metáfora militar. A Biblioteca torna-se fortaleza da Sabedoria que o estudante-soldado é chamado a conquistar. No interior, o espaço do conhecimento é dividido em três etapas progressivas: o espaço da adquisição dos novos saberes (Imago Bibliotecae); do conhecimento académico (Universitas) e do enciclopédico (Enciclopedia). Porém, o verdadeiro objetivo final é alcançar a sabedoria do Sabio Cristão, tal como a descreve padre Rafael

1 Investigadora do Centro de Estudos Sociais da Universidade de Coimbra giuseppinaraggi@ces.uc.pt 
Bluteau nas suas Prosas Academicas... (1717-1728). Chegando ao fim do seu percurso, depostas as armas aos pés do soberano, o estudante-conquistador espelha-se no retrato de rei D. João V, imagem vivente do Sabio Cristão. O texto aprofunda, também, os seguintes tópicos: 1) as conexões artísticas com a arquitetura italiana e austríaca; 2) as estreitas relações entre a pintura de arquiteturas em perspetiva, realizada nos três tetos da Biblioteca Joanina por António Simões Ribeiro e Vicente Nunes, e a tradição da "quadratura" bolonhesa; 3) a carência de fornecimento de livros para a Biblioteca da Universidade de Coimbra, depois da conclusão do edifício e ao longo da segunda metade do reino de $\mathrm{D}$. João $\mathrm{V}$; 4) a reinterpretação da quadratura dos tetos da Biblioteca Joanina por António Augusto Gonçalves no século XIX; 5) as obras de restauro promovidas pela Direção dos Monumentos Nacionais entre 1931 e 1934 e o envolvimento do pintor Joaquim Lopes, Professor de artes no Porto.

\section{PALAVRAS-CHAVE}

Biblioteca Joanina / Universidade de Coimbra / Rei de Portugal D. João V / Filippo Juvarra / Rafael Bluteau / Sabio Cristão / quadratura / António Simões Ribeiro / restauro dos tetos da Biblioteca Joanina

\section{ABSTRACT}

This article aims to rethink the process of the building and decoration of the Coimbra University Library known as the Biblioteca Joanina (1716-1728). It focuses on the artistic and cultural context of the first half of the reign of King John V (1707 - around 1728) and on the impact of the projects of the Italian architect Filippo Juvarra for the new city of Lisbon (1719). The building of the Biblioteca Joanina integrated the renovation plan in all the fields of knowledge promoted by King John V, Queen Maria Ana of Austria and the Portuguese court. Thus, this paper offers a new interpretation of the iconographic program, based on a military metaphor. The Library is like a fortress of the Sapience to be conquered by the student-soldier. Inside, the space of knowledge is divided into three progressive stages: the library (Imago Bibliotecae), the academic stage (Universitas), and the encyclopedic knowledge (Enciclopedia); however the true and final goal of the conquest is 
to achieve the wisdom of the Sapient Christian (Sabio Christão) as described by Father Rafael Bluteau in his Prosas Académicas... (1717-1728). At the end of his journey, with his weapons put down at the feet of the monarch, the student-conqueror reflects himself in the portrait of King John V, the Wise Christian King. Moreover, the paper highlights the following topics: 1) the artistic connections with the Italian and Austrian architecture; 2) the close relationship between the ceiling paintings by António Simões Ribeiro and the Bolognese painting tradition of "quadratura"; 3) the lack of books supplies after the completion of the Coimbra University Library and during the second half of the reign of King John V; 4) the (re)interpretation of the ceiling paintings by António Augusto Gonçalves in the 19th century; 5) the restoration works promoted by the Portuguese State between 1931 and 1934, and the involvement of the painter Joaquim Lopes, Professor of Arts in Porto.

\section{KEYWORDS}

Joanina Library / Coimbra University / King of Portugal John V / Filippo Juvarra / Rafael Bluteau / "Wise Christian" / quadratura painting / António Simões Ribeiro / restoration of the Joanina Library's ceiling paintings

A Biblioteca Joanina da Universidade de Coimbra é a única obra ainda existente do reinado de $\mathrm{D}$. João $\mathrm{V}$ realizada integralmente em época joanina e num prazo de tempo relativamente breve (1716-1728). ${ }^{2}$ Isto permite analisar a coerência do espaço ao nível arquitetónico, pictórico, iconográfico e simbólico. Através da sua leitura é possível vislumbrar, também, a magnificência dos grandiosos projetos pla-

2 Este artigo baseia-se na minha anterior pesquisa de pós-doutoramento (SFRH/ $\mathrm{BPD} / 38752 / 2007)$, no que diz respeito à quadratura, e no trabalho desenvolvido com o professor Vítor Murtinho do DARQ-UC entre 2010 e 2013 para a reconstrução da perspetiva e a sua relação com a geometria do espaço da Biblioteca Joanina. Propus repensar os projetos joaninos em Raggi, G. (2018). A cidade do rei e os teatros da rainha: (re)imaginando Lisboa ocidental e a Real Ópera do Tejo. Cadernos do Arquivo Municipal, 9, 97-124; Raggi, G. (no prelo). Repensando Mafra : o Real Edifício, Filippo Juvarra e a política arquitetónica de D. João V. In Pereira, P., Gorjão, S. (Ed), Do tratado à obra: génese da arte a da arquitetura no palácio de Mafra. Mafra : Câmara Municipal. 
nificados por D. João V para Lisboa, como capital da monarquia e do império português. De facto, a construção da nova biblioteca da universidade coincidiu com o período de maior efervescência cultural e de realização de projetos de todo o reinado. ${ }^{3}$

Este processo de transformação foi marcado inicialmente pela chegada da rainha Maria Ana de Áustria, em finais de 1708. Nos anos seguintes, foi alimentado pela projetada viagem europeia de D. João $\mathrm{V}$, que deveria ter durado dois anos (1715-1716), e foi definitivamente impulsionado pela elevação da capela-real em patriarcal em $1716 .{ }^{4}$ Em 1719, atingiu o ápice graças à chamada a Portugal do arquiteto Filippo Juvarra e do compositor Domenico Scarlatti, desdobrando-se, até acerca de 1725, em inúmeros projetos no campo urbanístico, arquitetónico, teatral, musical, artístico, que incluíam também a ampliação da biblioteca real do palácio da Ribeira e a formação das coleções reais. ${ }^{5}$ Em coincidência com a rotura das relações diplomáticas com a Santa Sé (1728-1732), a política artístico-cultural de D. João V focou-se na conclusão da basílica de Mafra e no efetivo arranque do estaleiro do convento e do palácio, mudando as dinâmicas culturais

3 Propus uma nova visão sobre as dinâmicas culturais do reinado joanino em RAGGI, G. (2017). L'effervescenza culturale del regno di Giovanni V di Portogallo (1707-1728): una visione controcorrente. In J. Martínez Millán, F. Labrador Arroyo, F. Valido-Viegas de Paula-Soares (Ed), Decadencia o reconfiguración? Las Monarquías de España y Portugal en el cambio de siglo (1640-1724). Madrid : Ediciones Polifemo, 317-337.

4 Raggi, G. (2017). Una lunga passione per l'opera in Portogallo: la regina-consorte Maria Anna d'Asburgo, I'arte dei Galli Bibiena e nuovi disegni per il Real Teatro dell'Opera do Tejo. In Frommel, S.; Antonucci, M. (Eds.), Da Bologna all'Europa: artisti bolognesi in Portogallo (secoli XVI-XIX). Bologna : Bononia University Press, 159-188; Raggi. G. (2018). O espaço teatral na corte de D. João V e o papel da rainha Maria Ana de Áustria na promoção de ópera em Portugal. In Yordanova, I; Maione, Serenata and Festa teatrale in 18th century Europe, Coleção Cadernos de Queluz 1. Viena : Hollitzer Verlag, 19-57.

5 Raggi, G. (2014). Filippo Juvarra a Lisbona: due progetti per un teatro regio e una complessa questione musicale. In E. Kieven, C. Ruggero (Ed). Filippo Juvarra (1678-1736): architetto dei Savoia, architetto in Europa. Roma: Campisano, 2014, vol. II, 209-228; Raggi, G. (2014). A idealização de dois projetos para o teatro régio e um novo desenho do arquiteto Filippo Juvarra para a corte portuguesa. Revista de História da Arte - Estudos de Lisboa, 11, 136-151. 
que tinham caraterizado as primeiras duas décadas do seu reinado. ${ }^{6}$ Como mostrarei, o projeto e a construção da Biblioteca colocam-se em correspondência cronológica com o momento mais significativo do período a que propus chamar "efervescência joanina"?

\section{O projeto da Biblioteca e a efervescência joanina} (1716-1717)

Como é sabido, o motivo inicial do projeto foi a possibilidade de comprar «huma grande Livraria que se vendia, parecendo [...] convinha muito à Universidade não perder tão boa ocasião de a redimir da injúria, que padecia entre os Estrangeiros e Nacionais». ${ }^{8} \mathrm{Em}$ 31 de julho de 1716, o reitor Nuno da Silva Teles comunicou à Mesa da Consciência e Ordens que a tinha arrematado por «quatorze mil cruzados», sendo necessário «para melhor acomodação della fazer-se hua Casa, por ser pequena, e escura a que ao presente há do dito Ministério, e no Pateo da mesma Universidade haver sitio, em que

6 Raggi, G. (2017). L'effervescenza culturale del regno di Giovanni V... Abordo mais aprofundadamente este tema no livro que estou a finalizar e cujo título provisório é: O projeto de D. João V. Lisboa ocidental, o Real Edifício de Mafra e o urbanismo cenográfico de Filippo Juvarra, cuja publicação concluirá as celebrações do $300^{\circ}$ aniversário da fundação da basílica e do palácio-convento de Mafra.

7 Veja-se a bibliografia referenciada nas notas acimas $\mathrm{nn}$. 2-5.

8 AUC, Provisões, Cartas, Alvarás, Livro 4 (1616-1746), fl. 44. A primeira carta sobre o pedido de licença para comprar a livraria de Francisco Barreto por doze mil cruzados foi enviada à Mesa da Consciência e Ordens em 8 de Junho de 1716. O pedido foi analisado pelos deputados da Mesa em 18 de Agosto e apresentado ao rei D. João $V$ em 31 de Agosto, sendo enviada a resposta ao reitor no dia 6 de Outubro de 1716. Sobre a Biblioteca Joanina veja-se, entre outros: Ferrão, P. M. (2015/2016). A Casa da Livraria da Universidade de Coimbra ao tempo de D. João V. Boletim da Biblioteca Geral da Universidade de Coimbra, 46/47, 63-72 com bibliografia precedente; Pimentel, A. F. (1998). Uma empresa esclarecida: a Biblioteca Joanina. Monumentos, 8, 49-51; Pimentel, A. F. (1998). Domus Sapientiae. O paço das escolas. Monumentos, 8, 35-40; Ferrão, P (1993). A construção da Casa da Livraria da Universidade de Coimbra. In Dias, P. (Ed.), Actas do colóquio. A Universidade e a Arte (1290-1990). Coimbra : Universidade de Coimbra, 85-127; Ramos Bandeira, J. (1943). Universidade de Coimbra. Edifícios do Corpo Central e Casa dos Melos, Coimbra : Universidade de Coimbra. 
sem muita despesa se poderá fazer, com os requisitos necessários». ${ }^{9}$ Em 31 de outubro de 1716, D. João V aprovou «mandar fazer a dita Casa, no sitio sobredito, como o mais útil e de menos despesa», ${ }^{10}$ concedendo também o «excesso dos dous mil cruzados, aos doze, de que tínheis faculdade minha para se dar por ella»..11 Apesar de, inicialmente, terem sido considerados os aspetos económicos e utilitários, o edifício, desde o seu acabamento, foi considerado uma obra magnífica. Em 1733, a Historia breve de Coimbra descreveu a Biblioteca como «uma grandiosa Livraria, com grandioso pórtico e magnifico edifício, que, enquanto ao material, por fora e por dentro está acabada; falta o ornato dos livros. Na direção, ordem e custo será uma das maravilhas da Europa, pois só no material da obra, pinturas e dourados [...] se tem gasto até ao ano de 1725 cento e cinquenta e oito mil e tantos cruzados. 0 custo dos livros de todas as Artes e Ciências chegará a soma extraordinária».12 Na documentação original, entre os deputados da Mesa da Consciência e Ordens que assinaram a provisão inicial, consta o padre Pedro Sanches Farinha de Baena que, entre 1719-1722, sucedeu ao reitorado de Nuno da Silva Teles (1715-1718). ${ }^{13}$

O reitor Nuno da Silva Teles era filho do $2 .^{\circ}$ marquês de Alegrete, D. Fernando Teles da Silva e pertencia à primeira nobreza da corte joanina. Em 1708, o seu pai tinha sido nomeado, por D. João V, embaixador extraordinário em Viena para concluir o tratado matrimonial e acompanhar a rainha Maria Ana de Áustria durante a sua longa viagem até Lisboa. O seu avô, D. Manuel Teles da Silva, tinha sido nomeado

9 AUC, Provisões, Cartas, Alvarás, Livro 4 (1616-1746), fl. 43.

10 Ibidem.

11 Ibidem.

12 Rodrigues, M. A. (1990). A Universidade de Coimbra e os seus reitores. Para uma história da Instituição. Coimbra : Arquivo da Universidade de Coimbra, 133.

13 A mesma provisão encontra-se também in ANTT, Mesa da Consciência e Ordens, Provisões, Maço 254, 1696-1719, fls. 154 r/v com indicação escrita ao lado: «Universidade. Caza da Livraria» 
por D. Pedro Il embaixador extraordinário à corte do eleitor palatino do Reino para negociar os termos do seu segundo casamento com Maria Sofia de Neuburgo, mãe de D. João V. ${ }^{14} \mathrm{O}$ seu tio homónimo, Nuno da Silva Teles, ${ }^{15}$ tinha sido reitor da Universidade de Coimbra entre 1694 e 1702, demonstrando grande interesse pela arquitetura e promovendo uma intensa campanha de obras destinadas a:

tratarem do concerto de alguns Geraes, e alargarem outros de forma conveniente, e fazerem de novo dous, que hajão de servir hum de Instituta e outro de Theologia, porque os que existem destas faculdades hum possa servir de Livraria da Universidade; e outro para se ler matemática, conductas e cursos de leitura, que se deixão de ler por faltar comodidade, e Geral para ellas. E além da necessidade, será esta obra sumamente útil para a formusura dos Gerais, por que ficarão todos em esquadrias, e para ella se acha a Universidade com a conveniência de ter meyas feitas as paredes nos muros que fechão em quadro a ária dos Gerais, e haver no cofre da Universidade todo o dinheiro que basta para esta despeza. ${ }^{16}$

Funcionalidade e formosura norteavam os intentos do primeiro reitor da Casa dos Alegretes que, em 1695, fixou a sede da biblioteca da Universidade nos Gerais. ${ }^{17}$ As obras envolveram o escultor Claude de Laprade para a realização das insígnias e do busto de D. Pedro II. ${ }^{18}$ Em 1715, logo após a nomeação como reitor, o seu sobrinho fo-

14 Miranda, S. Münch, Miranda, T. C. P. dos Reis (2014). A rainha arquiduquesa: Maria Ana de Áustria. Maia : Círculo de Leitores, 103. Ao regresso desta embaixada extraordinária, D. Pedro II concedeu a D. Manuel Teles da Silva, $2^{\circ}$ conde de Vilar Maior o título de $1^{\circ}$ marquês de Alegrete.

15 Era filho do $10^{\circ}$ marquês de Alegrete e irmão do $2^{\circ}$ marquês de Alegrete, D. Ferdinando Teles da Silva

16 ANTT, Mesa da Consciência e Ordens, Universidade de Coimbra, maço 60, fls s.n., datada Julho-Agosto de 1695.

17 Rodrigues (1990), 127; Pimentel (1998). Domus Sapientiae...

18 Rodrigues (1990), 127. 
cou também a atenção na promoção de uma ampla campanha de obras face às condições precárias em que se encontrava, outra vez, o conjunto arquitetónico. Resolveu, como acima referido, mudar a localização da biblioteca para o pátio, mantendo a continuidade com a escolha do seu antepassado. Porém, a magnificência do edifício, ainda hoje apreciável em todo o seu esplendor, parece contradizer a primeira intenção do reitor, explicitada à Mesa da Consciência e Ordens em 1716, de o mandar construir «sem muita despesa» ${ }^{19}$.

Nos meses em que correram estes primeiros diálogos entre o reitor e os deputados da Mesa, outros eventos estavam a acontecer. No início de julho, o marquês de Fontes fizera a sua magnífica entrada pública em Roma, alcançando para o monarca português a desejada elevação da capela-real em patriarcal. A notícia foi antecipada pelo núncio apostólico em agosto, mas somente em dezembro de 1716 a bula pontifícia chegou a Portugal. ${ }^{20} \mathrm{D}$. João V estava impaciente de a receber, ordenando, desde a comunicação informal, ao conde de Redondo de mandar traçar o mapa de Lisboa, dividida entre a parte ocidental e a oriental, pelo jovem engenheiro Manuel da Maia. ${ }^{21}$ A partir deste momento, a vontade de renovação artístico-cultural demonstrada desde o início do seu reinado transformou-se na entusiástica intenção de construir a nova Lisboa ocidental. Esta circunstância determinou um contínuo fluxo de projetos entre Roma e Lisboa, visando tanto na nova basílica e palácio patriarcais, quanto na renovação do palácio real da Ribeira que devia estender-se até ao palácio Corte-Real [fig.1]. Neste processo, o arquiteto italiano

19 AUC, Provisões, Cartas, Alvarás, Livro 4 (1616-1746), fl. 43.

20 Roma, Archivio Segreto Vaticano [ASV], Segr. Stato, Portogallo 76. Neste documento, entre agosto e dezembro de 1716, encontram-se inúmeras referências sobre $o$ assunto.

21 Rossa, W. (2017). Juvarra: cenografia e urbanística para uma capital do lluminismo. Estudos Italianos em Portugal, 12, 271-294, com bibliografia precedente. Raggi, G. (2018). A cidade do rei... 
Filippo Juvarra adquiriu um papel de relevância fundamental. Durante a sua estada em Portugal, de janeiro a julho de 1719, o primeiro

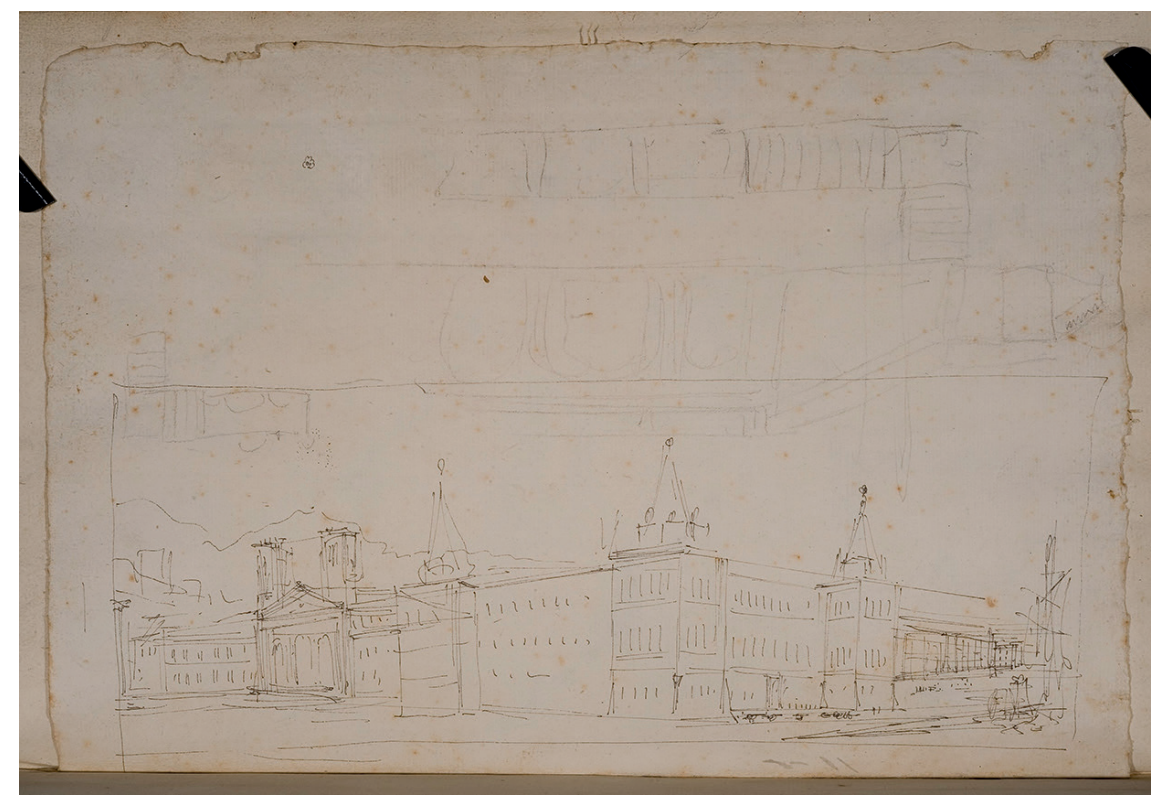

Fig. 1

Filippo Juvarra - Ideia para o primeiro projeto do palácio real, basílica e palácio patriarcais na Ribeira, 1717-1719. Torino : Biblioteca Nazionale Universitaria di Torino, Ris. 59.6, fl. 22v

projeto elaborado em Roma junto ao marquês de Fontes foi substituído por outro ainda mais grandioso e urbanisticamente cenográfico. Neste processo participou ativamente o $2 .^{\circ}$ marquês de Alegrete, pai do reitor Nuno da Silva Teles. Ele estava presente no encontro de fevereiro de 1719 no sítio da Cruz de Buenos Aires, quando nasceu a ideia de mudar a localização do principal palácio real. De facto, D. João V:

mandou chamar à sua Real presença em 7 de Fevereiro de 1719 alguns Fidalgos, Ministros e Medicos pelo que tocava à eleição de hum sitio saudável, e Arquitectos, que dirigissem a projecção da grande obra, que intentava [...] Os Medicos assentaraõ uniformemente [... ] reconheciam em Buenos Aires todas as vantagens, que a Filosofia 
natural, e a Medicina procuravam no caso proposto. Os mais votos se dividirão; porque os Marquezes de Abrantes, e Minas, o conde de Assumar, e Padre D. Manoel Caetano de Sousa, Mons. Berger se inclinavão a edificar no terreiro do Paço. O Marquez de Alegrete, os Condes de Aveiras, Unhão, Ericeira, Valladares e São Lourenco e Federico [Ludovice] foraõ de parecer que se preferisse Buenos Aires, D. Filippe Ibarra [sic Juvarra] principal Arquitecto Siciliano, não declarou o seu voto. $^{22}$

Esta versão dos acontecimentos, publicada em 1763-1764 por João de Castro em Mappa de Portugal, pode ser integrada agora por uma fonte primária, e coeva dos factos, que complementa as conhecidas cartas do núncio apostólico. ${ }^{23}$ Trata-se da correspondência diplomática do residente imperial Giuseppe Zignoni e restitui uma contextualização histórica mais atenta às artes profanas (ópera, dança, serões de corte) e à arquitetura palaciana. O encontro de fevereiro de 1719 incluía, também, a discussão sobre o melhor lugar para o palácio real de recreio, «a Régia Casa de Campo»:

Sabado $S^{a} M^{a}$ foi outra vez com ele [Filippo Juvarra] fora da cidade, num sitio muito alto chamado a Cruz de Buenos Ayres, próximo do rio para mandar medir e examinar aquele terreno para edificar, como se diz, uma Régia Casa de Campo, ou para o destinar para outra ideia. $S^{a} M^{a}$ desejou que a $M^{a}$ da Rainha fosse até lá ao mesmo tempo [...] e

22 Castro, J. B. (1763-1764). Mappa de Portugal Antigo e Moderno. Lisboa : Francisco Luiz Ameno, tomo III, 193-194.

23 Raggi, G. (2017). Filippo Juvarra in Portogallo: documenti inediti per i progetti di Lisbona e Mafra. ArcHistoR. 7, 33-71; Scotti, A. (1973). L'Accademia degli Arcadi in Roma e i suoi rapporti com la cultura portoghese nel primo ventennio del 1700. Bracara Augusta, XXVII, 63 (75), 115-130. 
ela chegando no dito lugar [de Alcântara] prosseguiu em cadeirinha [...] emquanto o Rei andou a cavalo. ${ }^{24}$

A escolha do sítio de Buenos Aires para o principal palácio da monarquia portuguesa foi baseada nos pareceres dos médicos e à luz dos novos conhecimentos da «filosofia natural». ${ }^{25}$ Como veremos, estas matérias caraterizam a novidade do programa iconográfico da primeira sala da Biblioteca Joanina. Por isso, entre a intenção de julho de 1716 de construir o edifício «sem muita despesa» e a colocação da primeira pedra, em 17 de julho de 1717, a "efervescência joanina" acelerou o seu ritmo, influenciando o projeto da biblioteca da Universidade de Coimbra. A biblioteca real do palácio da Ribeira também começou a ser enriquecida, até multiplicar exponencialmente o seu acervo nos anos Vinte. ${ }^{26}$ Como referido, Filippo Juvarra permaneceu em Lisboa de janeiro a julho de 1719. Em 1 de junho de 1719, Nuno da Silva Teles acabou o seu cargo trienal e o novo reitor da Universidade de Coimbra «foi nomeado diretamente pelo rei [...] sem prévia escolha do Conselho». ${ }^{27}$ Tratava-se de Pedro Sanches Farinha de Baena, acumulando o cargo com o que já detinha na Mesa da Consciência e Ordens. ${ }^{28}$ Tendo sido ele um dos deputados que assinaram a provisão de 31 de outubro

24 Vienna, Haus-, Hof- und Staatsarchiv [HHStA], Portugal 6, 6-2, c. 133r.-v. (14 de fevereiro de 1719): «Sabbato la M.S. ritornò con lui fuori di città a un sito molto alto, chiamato la croce di Buenos Ayres vicino al fiume per far misurare, ed esaminare quel terreno per fabbricarvi, come si dice, una Casa di Campo reggia, o per servirsene per altra idea. S. M.à desiderò, che la M.tà della Regina si trasferisse colà all'istesso tempo, e la M.S. per compiacere al Re pranzò, e partì con tanta fretta, che la mag.or parte degli uffiziali di sua Casa non stavano pronti per accompagnarla all'uscire da Palazzo, e gionta al do in loco, seguì in sedia volante con la S.ra Infante dona Francesca, il Re che girava a cavallo, e di là si portò alla solita divozione das Necessidades». Tradução da autora.

25 Castro (1763-1764), 193-194.

26 Almeida, L. Ferrand de (1991). D. João V e a Biblioteca Real. Revista da Universidade de Coimbra, 36, 413-430.

27 Rodrigues (1990), 135.

28 Ibidem. 
de 1716 relativa à construção da Biblioteca, a sua nomeação por expressa vontade do rei confirma a inclusão do edifício no grandioso programa de planificação da nova capital imperial e patriarcal, cuja potência se fundamentava, também, sobre o novo conhecimento reunido na "fortaleza" da sabedoria na Universidade de Coimbra. ${ }^{29}$

\section{Arquitetura e quadratura como metáforas da conquista}

As três salas da Biblioteca Joanina e, principalmente, as pinturas de quadratura que decoram seus tetos ilustram visualmente um percurso por etapas que começa no espaço exterior do próprio edifício [fig. 2].

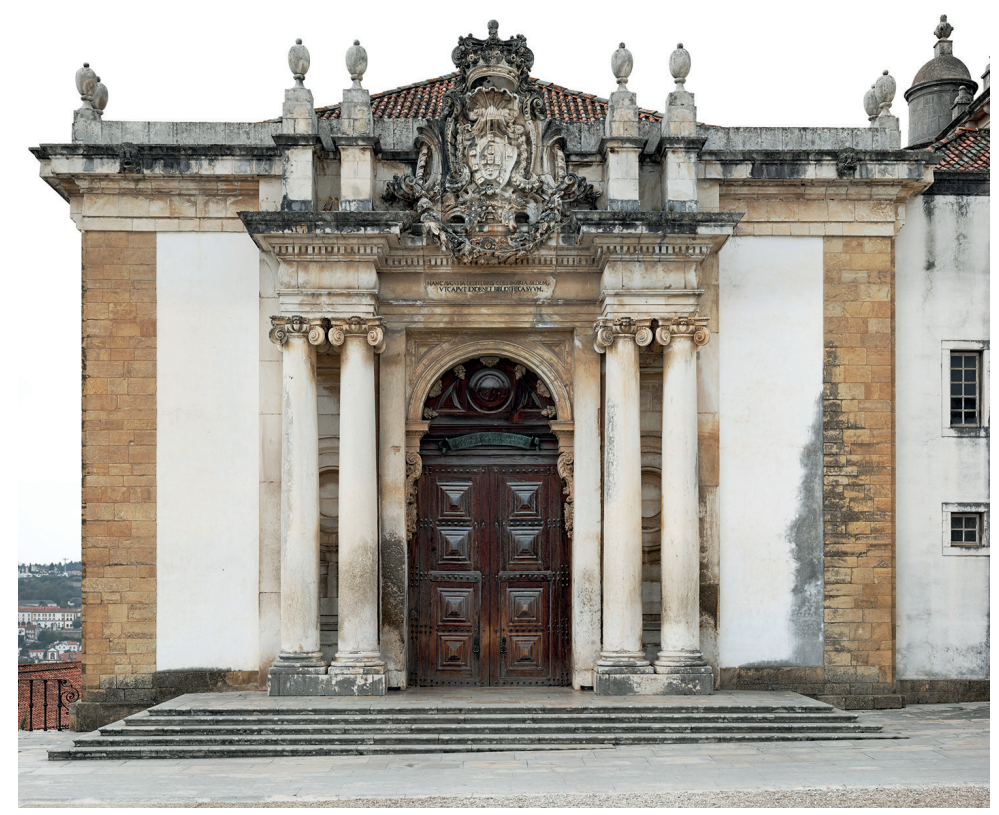

Fig. 2

Fachada da Biblioteca Joanina, 1716-1728

29 Falecido de repente em março de 1722, até finais do ano o vice-reitor assumiu o cargo. D. João $V$ continuou a reservar para si a eleição, também, do sucessor de Baena. O rei escolheu para o triênio de 1723-1726, Francisco Carneiro de Figueiroa que foi reconduzido até a jubilação, em 1737. Rodrigues (1990), 137. 
Por cima do portal de entrada, as palavras gravadas na pedra do entablamento identificam-no como «a sede que a Augusta Coimbra deu aos livros, para que a biblioteca a coroe» [fig. 3]. ${ }^{30}$

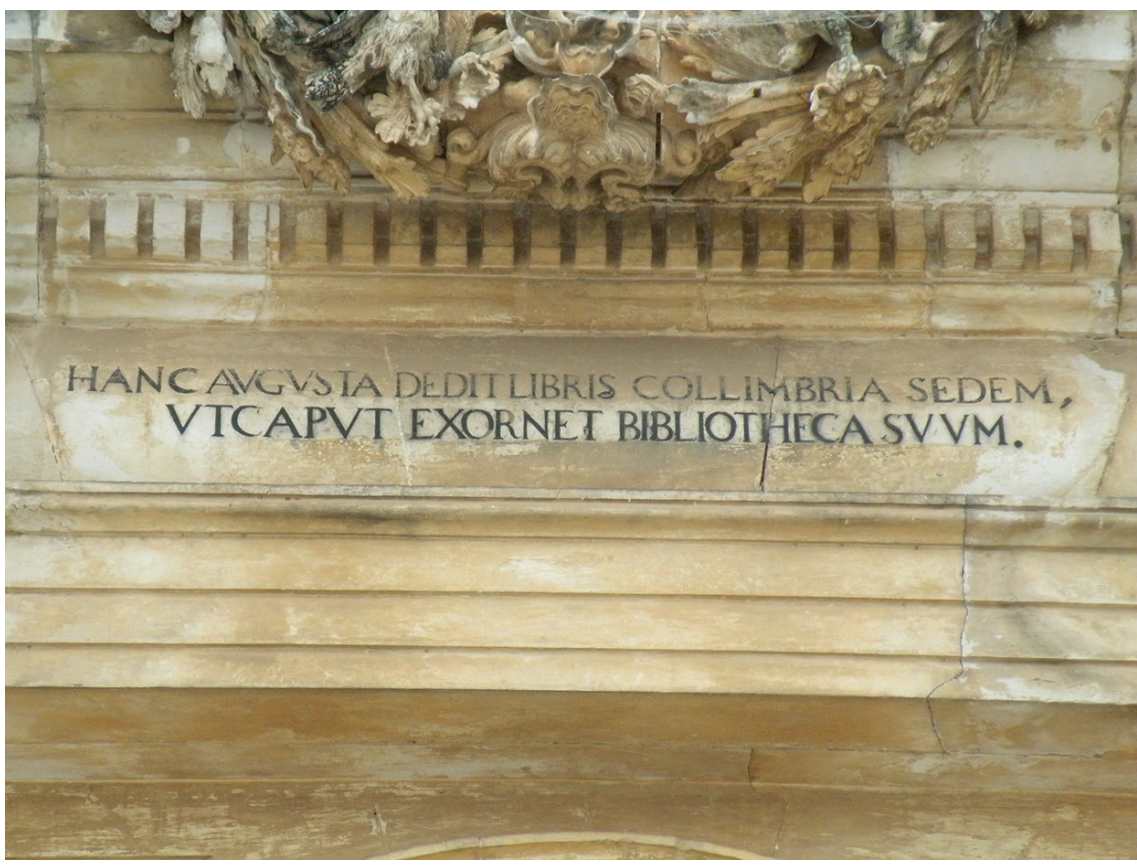

Fig. 3

Portal da Biblioteca Joanina, pormenor, 1716-1728. Foto da autora

O atributo de «Augusta» dado à cidade da principal universidade do reino e do império ultramarino português, onde não havia instituições de ensino universitário, identifica a biblioteca com a metáfora da «coroa», relacionada quer com a coroa régia, quer com a coroa de louros atribuída na antiga Roma aos vencedores durante os Triunfos, as entradas solenes dos conquistadores do antigo império romano.

30 Hanc Augusta dedit libris Collimbria sedem, ut caput exornet Bibliotheca suum. Tradução minha do latim. 
A conexão com a metáfora da conquista encontra-se explicitada na tarja de latão: «Lusos, a Sapiência fundou para vós esta fortaleza; por capitães [tendes] os livros, por soldados e armas o trabalho» ${ }^{31}$ [fig. 4].

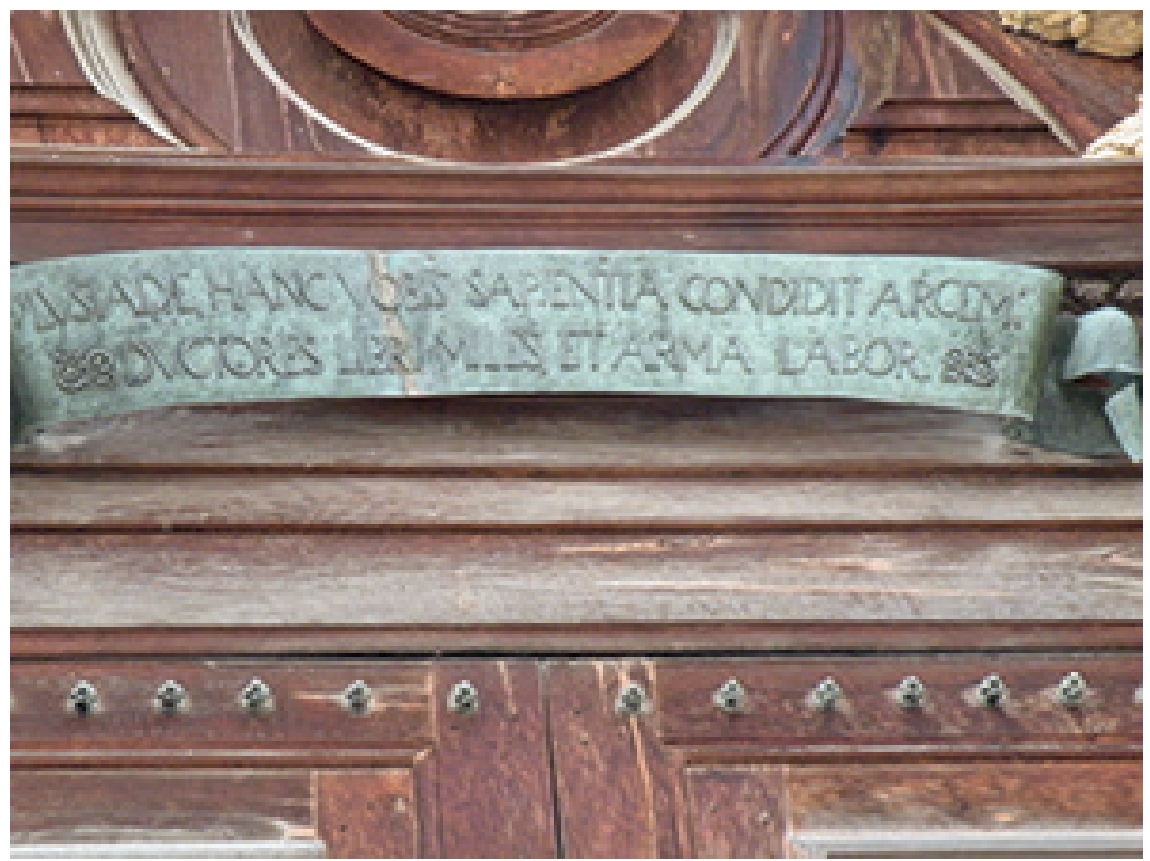

Fig. 4

Portal da Biblioteca Joanina, pormenor. 1716-1728. Foto da autora

A biblioteca torna-se fortaleza a expugnar, cittadella a conquistar pelos estudantes, conduzidos pelos «livros» como seus «capitães»e pelo estudo como força («os soldados») e instrumento («as armas»). A finalidade é penetrarem até conquistar integralmente o espaço, chegando ao ponto nevrálgico do poder que a fortaleza-biblioteca representa. De facto, «as armas» estão depostas aos pés do retrato do rei $D$. João $V$ que, desde a entrada, se oferece como o principal foco visual [fig. 5].

31 Lusiadae, hanc vobis Sapientia condidit arcem: ductores libri; miles et arma labor. 
Assim, dado o primeiro passo e ultrapassado o limiar do portal, a figura do rei representado em tamanho natural convida a avançar para a conquista da Sabedoria. O teor peculiar desta "ação militar" é explicitado pela tarja colocada no interior da porta de entrada, isto é, atrás de quem entra e visível somente depois de ter contemplado o caminho a fazer através das três salas. ${ }^{32} \mathrm{~A}$ conquista procede por etapas e a fortaleza transforma-se, no seu interior, num palácio onde a enfilade das três salas determina a progressiva aproximação ao rei. Como explicita o uso do plural na frase latina, cada sala da biblioteca é entendida como «palácio por livros adornado» ${ }^{33}$ onde se deve ler, meditar e adquirir o conhecimento aí reunido, antes de passar à sala seguinte.

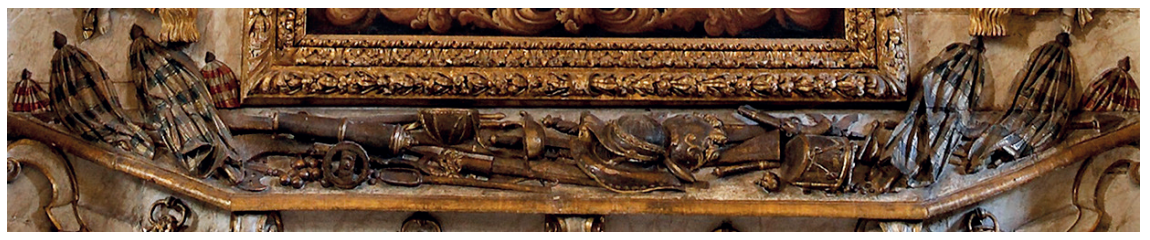

Fig. 5

Armas em talha, pormenor da moldura do retrato de D. João V.

Foto de Vítor Murtinho

O espaço arquitetónico de cada sala é ampliado virtualmente graças à pintura de quadratura dos seus tetos. Esta arte foi desenvolvida pelos mestres de pintura a fresco e de cenografia da cidade de Bolonha, em Itália, na primeira metade do século XVII. ${ }^{34}$ A quadratura incide na arquitetura real, dilatando-a em espaços arquitetónicos verosímeis através da aplicação das regras da perspetiva, das ordens e dos modelos de arquitetura codificados pelos tratados do século XVI. Por isso, a escolha da quadratura justifica-se não somente pelo sucesso desta arte na corte e na sociedade portuguesa

32 Pandutur cuntis exculta palatia libris: huc ades; autores consule, doctus eris. Haec tibi pro studiid et lex et norma teneta est: mens legat, obsevet sédula; penna notet.

33 Idibem

34 Raggi, G. (2013). Ilusionismos. Os tetos pintados do Palácio Alvor. Lisboa : DGPC. 
depois da chegada a Lisboa do quadraturista-cenógrafo florentino Vincenzo Bacherelli ${ }^{35}$ mas, sobretudo, pela peculiaridade intrínseca de 'edificar' visualmente os mundos simbólicos a representar. Graças à quadratura, cada sala da Biblioteca multiplica a carga imagética e metafórica do espaço arquitetónico.

Assim, o espaço global da Biblioteca, como fortaleza da Sabedoria, constrói-se através de progressivos graus de conhecimento, representados pelas três alegorias pintadas no topo dos tetos: Imago Bibliotecae, Universitas, e Enciclopedia.

Do ponto de vista das matérias, a primeira sala testemunha a renovação do conhecimento graças à introdução da filosofia natural como ciência do conhecimento da realidade do mundo. $O$ espaço arquitetónico da sala é delimitado pelos brasões dos cursos de Matemática e de Medicina: o primeiro ensinado até então como curso livre e o segundo caraterizado pela profunda renovação do século anterior. ${ }^{36} \mathrm{~A}$ importância atribuída aos pareceres dos médicos relativos às condições de salubridade do sítio de Buenos Aires em comparação à área da Ribeira, ${ }^{37}$ durante o citado encontro de fevereiro de 1719, é confirmada pela iconografia da primeira sala. As alegorias dos Quatro continentes representados nas sancas do teto, sentadas sobre tímpanos pintados, ilustram a amplitude do conhecimento, que abrange todos os conteúdos fornecidos pelas diversas caraterísticas das quatro partes do mundo [fig. 6]. Considerando o vasto repertório ainda existente, a representação dos Quatro Continentes aparece pela primeira vez, no âmbito da qua-

35 Ibidem. Raggi, G. (2018). Architettura versus Pittura. Modi di intendere la quadratura e la pittura murale tra Spagna, Portogallo e Brasile coloniale. In J. M. Almansa Moreno, N. Martínez Jiménez, F. Quiles García (Ed), Pintura mural en la Edad Moderna entre Andalucía e Iberoamérica, Sevilla : ERA, 288-311.

36 Tal como a Biblioteca foi aberta somente em 1778, o curso de Matemática foi instituído apenas no tempo da reforma pombalina. Sobre os livros de medicina em Portugal veja-se Cardoso, A.; Oliveira, A. Braz de; Marques, M. S. (2019). Arte médica e imagem do corpo de Hipócrates ao final do século XVIII. Lisboa : Biblioteca Nacional.

37 Castro (1763-1764), 193-194. 
dratura luso-brasileira, nesta sala da Biblioteca Joanina, testemunhando a vocação universal e a motivação imperial da "conquista da Sabedoria".

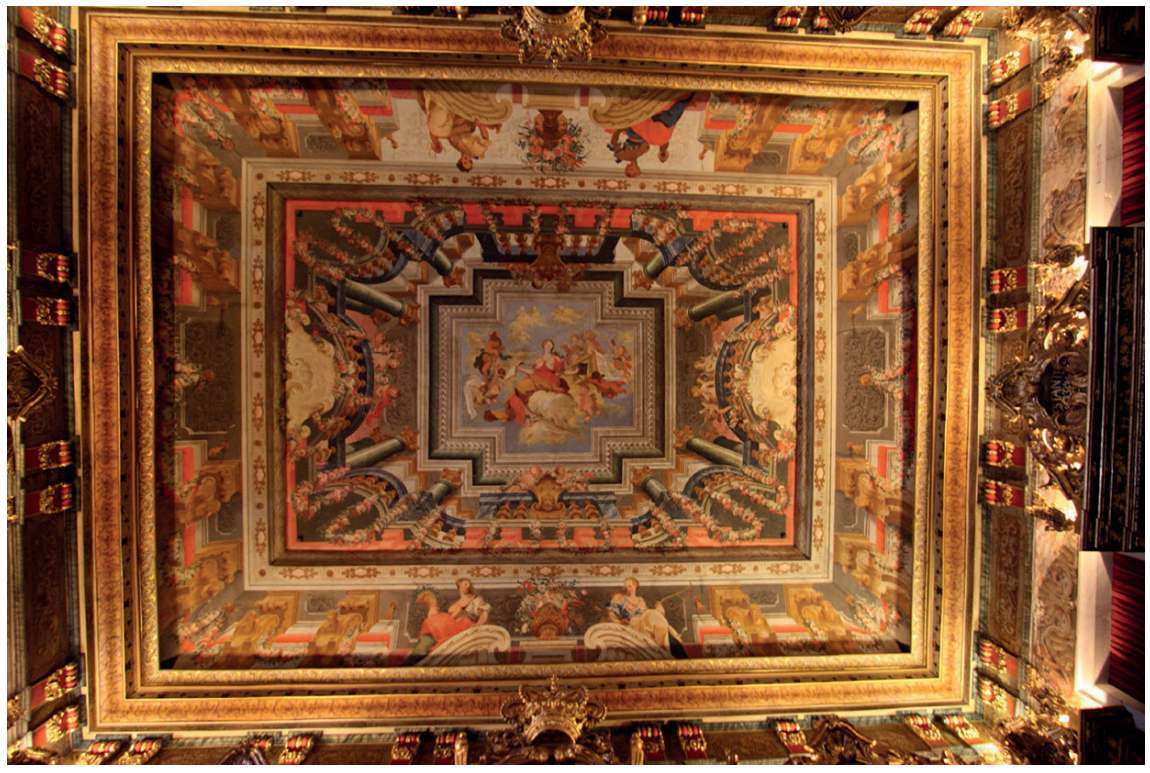

Fig. 6

António Simões Ribeiro e Vicente Nunes - Imago Bibliotecae, teto da primeira sala, 1723-1724. Foto de Vítor Murtinho

A renovação introduzida no âmbito da filosofia natural é declarada no topo do teto. Diferentemente das outras duas salas, a escolha iconográfica não utiliza imagens e palavras próprias da tradição clássica, mas inventa-as de raiz. O nome atribuído à figura feminina, Imago Bibliotecae, identifica a alegoria com a própria Biblioteca espelhada em si, no ato de se deleitar com os livros, tirando-os e pondo-os nas estantes. Neste jogo de auto-reflexão, celebra-se a novidade do saber reunido na primeira sala e a vontade de atualização do conhecimento subjacente ao desenvolvimento do projeto da Biblioteca Joanina. A filactera reforça o mesmo conceito, afirmando a «felicidade» ${ }^{38}$

38 Felices ornent haec instrumenta libelos. 
por estarem presentes, nas estantes da primeira sala, os livros do conhecimento atualizado nos campos da filosofia natural, da medicina e da matemática. A frase aponta para a novidade e a alegria emocional que derivam desta nova sabedoria sobre a realidade física do mundo.

O espaço da segunda sala é delimitado pelas insígnias das Faculdades de Cânones e de Leis. No Vocabulário Portuguez, Rafael Bluteau define a «Universitas» como «um ajuntamento de muitas aulas, classes, escolas, colégios, mestres e discípulos aos quaes universalmente se ensina todo o gênero de saber mais necessário para a vida natural, a Medicina; para a vida civil, a Jurisprudência; para a vida Cristã e Catholica, a Theologia» ${ }^{39}$. Na segunda etapa da conquista da sabedoria, a universidade de Coimbra espelha-se em si própria. O padre teatino descreve os três campos de aplicação do saber: a vida natural, a civil e a vida cristã, cuja tripartição revela uma estreita afinidade com o percurso espacial e iconográfico da Biblioteca Joanina.

A alegoria feminina da Universitas eleva-se no topo do teto graças à convergência perspética das arquiteturas pintadas em sottinsu sobre o tabuado do plano central [fig 7]. ${ }^{40}$

39 Bluteau, R. (1712- ). Vocabulario portuguez e latino.... Coimbra : Colégio das Artes da Companhia de Jesus, ad vocem

40 A análise da construção da perspetiva será apresentada no livro a publicar em parceria com Vítor Murtinho. 


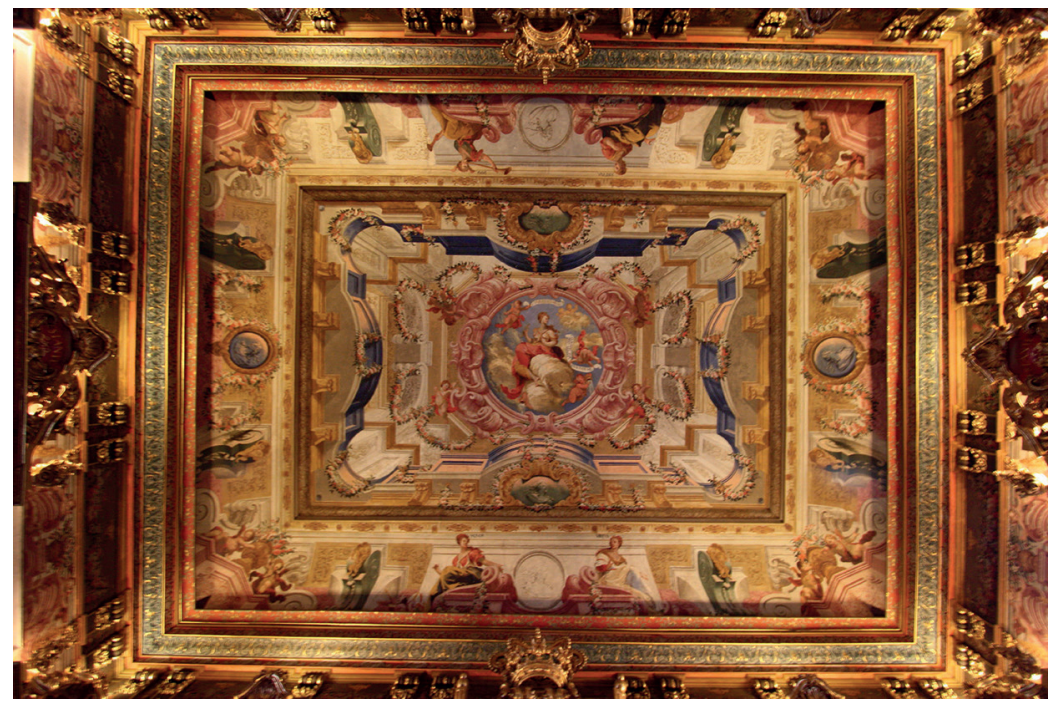

Fig. 7

António Simões Ribeiro e Vicente Nunes - Universitas, teto da segunda sala, 1723-1724. Foto de Vítor Murtinho

Nas sancas da base, as alegorias da Honra, Virtude, Fama e Fortuna ladeiam os bustos de Virgílio, Ovídio, Séneca e Cícero declarando a cultura clássica como os alicerces do ensino universitário. No significado simbólico global do programa iconográfico, a Universidade representa, também, o lugar da reflexão e do debate: a figura feminina dispensa com a mão esquerda o leite do conhecimento, segurando na mão direita a lâmina afiada do discernimento. A filactera enuncia a finalidade destes dois instrumentos: a abundância do saber e o exercício crítico sobre ele. O texto cita literalmente o verso final da IIla écloga de Virgílio. ${ }^{41} \mathrm{Na}$ exegese publicada por Lionel da Costa Lusitano, em 1624, o fecho desta composição poética é explicado pela vontade do autor de «mostrar primeiro as contendas e altercações dos dous pastores e logo o juiz [Palemon] e finalmente a sentença que compõe tudo», de forma que o verso final significa metaforicamente

41 Claudite iam rivos pueri, sat prata biberunt. Fechai, meninos, as regas, que os prados já beberam bastantes. 
«deixai de cantar [...] já estamos bem satisfeitos». ${ }^{42}$ Ter alcançado os conhecimentos reunidos na primeira e na segunda sala e aplicado neles os métodos e os instrumentos para os compreenderem e criticarem intelectualmente, permite ao estudante-conquistador ultrapassar o limiar da terceira e última sala: a da Enciclopédia ou, mais especificamente, a da perfeição da ação sábia.

Delimitada pelos brasões das faculdades de Retórica e Teologia, a Enciclopédia representa o grau mais amplo da sabedoria, pois inclui todas as faculdades representadas alegoricamente nas sancas do teto: Natura, Artes, Astrea, Sacra Pagina, cujas filactérias multiplicam os saberes transmitidos (Teologia, Cânones, Justiça, Medicina, Matemática, Filosofia, Artes, Gramática, Retórica, Música). ${ }^{43}$ Os efeitos benéficos do valor enciclopédico da sabedoria estão representados nos cartouches pintados em grisalha nos ângulos do teto: Concordia, Razão, Fidelidade e Felicidade pública. ${ }^{44}$ [fig. 8]

42 Costa Lusitano, L. (1761). As eclogas e georgicas de Vergilio... Lisboa : oficina M. Manescal da Costa, (1a edição 1624).

43 Ferrão (2015-2016), 70.

44 Sobral, L. de Moura (2011). Gravuras e hermenêutica. Os casos da chamada Sala dos Encantos da Música do Paço Ducal de Vila Viçosa e da Sala da Enciclopédia da Biblioteca Joanina de Coimbra. In I. Mendonça, A. Paula Rebelo Correia (Ed.), III Colóquio de Artes Decorativas: Iconografia e fontes de inspiração. Imagem e memória da gravura europeia. Lisboa : Fundação Ricardo do Espírito Santo Silva, 193-202. 


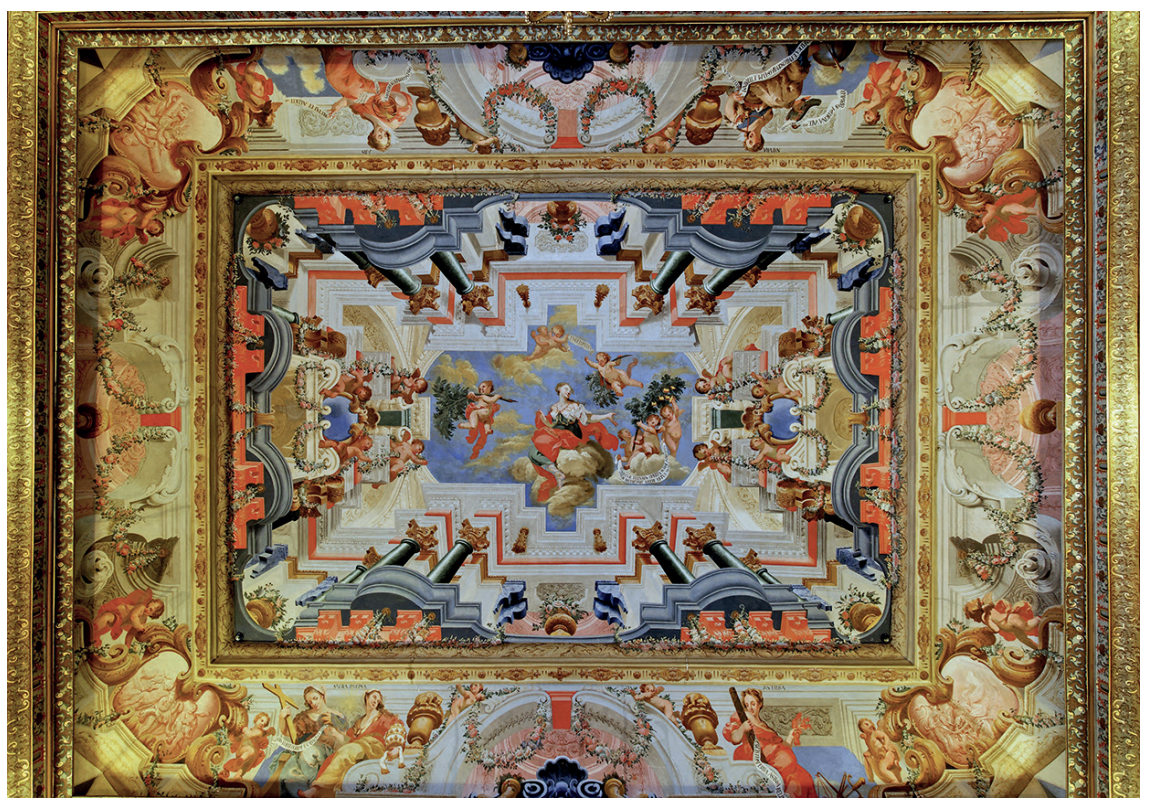

Fig. 8

António Simões Ribeiro e Vicente Nunes - Enciclopedia, teto da terceira sala, 1723-1724. Foto de Paulo Mendes

A denominação escolhida para o terceiro, e mais alto, grau da sabedoria conquistada no interior da fortaleza da Biblioteca Joanina remete para as correntes contemporâneas do pensamento iluminista do Setecentos europeu. ${ }^{45}$ Porém, um elemento iconográfico ignorado pelos estudos críticos fornece, a meu ver, uma chave de leitura mais original: os olhos da Enciclopédia estão vedados por um finíssimo véu e o seu braço indica um ramo carregado de livrinhos dourados como seus frutos [fig. 9].

45 Pimentel (1998); Sobral (2011). 


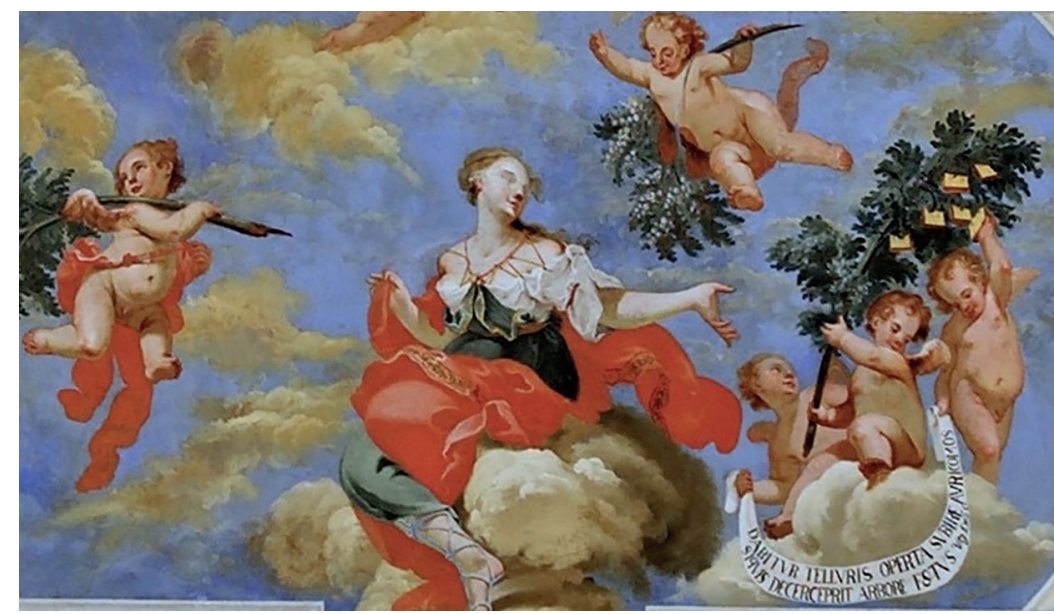

Fig. 9

António Simões Ribeiro e Vicente Nunes - Enciclopedia, pormenor, teto da terceira sala, 1723-1724. Foto de Paulo Mendes

\section{Sábio Cristão e a Biblioteca do mundo}

Mais uma vez, Virgílio é escolhido como guia, sendo citados, no lema, dois hendecassílabos do IVo livro da Eneida: «Não é concedido penetrar nos segredos da Terra, sem antes ter colhido da árvore o rebento das folhas de ouro». ${ }^{46}$ Os versos fazem parte do vaticínio pronunciado pela Sibila de Cuma em resposta ao pedido de Eneias de conhecer o modo de ultrapassar o limiar do reino dos mortos:

[...] Latet arbore opaca / aureus et foliis et lento vimine ramus / lunonis infernae dictus sacer / hunc tegit omnis / lucus et obscuris claudunt convallibus umbrae. / Sed non ante datur telluris operta subire, / auricomos quam quis decerpserit arbore fetus; / hoc sibi pulchra suum ferri Proserpina munus / instituit; primo avolso non deficit alter / aureus et simili frondescit virga metallo. / Ergo alte vestigia oculis et rite repertum / carpe manu; namque ipse volens facilisque

46 Sed non ante datur telluris operta subire, auricomos quam quis decerpserit arbore fetus. Veja-se nota seguinte. 
sequetur, / si te fata vocant; aliter non viribus ullis / vincere nec duro poteris convellere ferro. ${ }^{47}$

Para penetrar no Hades é necessário oferecer à Proserpina o ramo de ouro escondido nas sombras de uma impenetrável floresta próxima do antro da Sibila. A profetiza declara que o ramo se deixará remover sem dificuldade, puxando-o simplesmente com a mão, se o fado escolher o herói; se não, nem com a força, nem com a faca conseguirá pegá-lo. Eneias pede ajuda à mãe Vénus. A deusa envia-Ihe duas pombas brancas, que lhe indicam o lugar. Eneias consegue achar e pegar sem muito esforço o ramo de ouro:

pascentes illae tantum prodire volando, / quantum aciem possent oculi servare sequentum. / Inde ubi venere ad fauces grave olentis Averni, I tollunt se celeres liquidumque per aëra lapsae / sedibus optatis gemina super arbore sidunt, / discolor unde auri per ramos aura refulsit. / Quale solet silvis brumali frigore viscum / fronde virere nova, quod non sua seminat arbos, / et croceo fetu teretis circumdare truncos, / talis erat species auri frondentis opaca / ilice, sic leni crepitabat brattea vento. / Corripit Aeneas extemplo avidusque refringit / cunctantem et vatis portat sub tecta Sibyllae. ${ }^{48}$

47 Aen.VI, 136-148. Tradução italiana por Enzio Cetrangolo (1988): Vergilio. Eneide. Firenze : Sansoni Editore, 243:

Nascosto in un albero folto è un ramo che ha foglie / d'oro e il gambo flessibile, sacro a Proserpina; / tutta la selva lo copre e fitte ombre lo cingono / di convalli. A nessuno è dato di entrare nei regni / segreti se prima non svelle quell'aureo germoglio. / La bella Prosèrpina vuole che a lei si riserbi / questo tributo; al primo staccato non manca il secondo / d'oro anch'esso, e il ramo di foglie d'oro si veste. / Dunque ben addentro osserva con gli occhi e trovatolo, / come il rito prescrive, staccalo con la tua mano; / quello da sé docilmente verrà alla tua mano / se il fato ti elegge, altrimenti non forza ti giova/ a piegarlo, né duro ferro a strapparlo.

48 Aen.VI, 190-211. Tradução italiana por Enzio Cetrangolo (1988): Virgilio. Eneide. Firenze : Sansoni Editore, 243:

Quelle a volo beccando tanto andavano innanzi / quanto gli occhi potessero intenti guardarle. / E quando alla bocca del livido Averno pervennero / veloci si levano a volo e dal limpido aere calando / si posan su l'albero strano, di doppia natura,/ donde rifulse tra i rami un vivido d'oro / scintillio. Quale d'inverno il vischio nei 
Virgílio atribui dupla natureza à árvore onde está escondido o ramo de ouro, que se parece como o visco nos bosques. Na natureza, o visco cresce implantando-se sobre outras árvores, produz bagas de cor de pérola e, no inverno, torna-se cor do ouro. No teto da terceira sala da Biblioteca Joanina, três ramos circundam a Enciclopédia: um é verde, outro mostra bagas-pérolas, o terceiro, o qual aponta a figura feminina e que traz a filactera, carrega como frutos livrinhos de ouro. Mais uma vez, regressa no programa iconográfico global uma simbologia tripartida: os três ramos como três graus progressivos de amadurecimento, até dar o fruto mais precioso: o ramo de ouro.

Conseguindo alcançar o visco - ramo de ouro, Eneias demonstra ser o escolhido pelo destino. Entrando no reino dos mortos, encontra o pai Anquises e escuta a profecia da fundação de uma nova cidade (Roma) e de uma nova estirpe (os romanos e o império). A escolha dos dois hendecassílabos revela intrínseca coincidência com as motivações que estavam a ser elaboradas entre Lisboa e Roma, desde 1716-1717, em relação à nova cidade de Lisboa ocidental, como capital imperial e patriarcal e à afirmação do poder da monarquia portuguesa, encarnado pelo rei $\mathrm{D}$. João $\mathrm{V}$.

O facto de a Enciclopédia ser representada vendada indica um elemento-chave pela hermenêutica global da terceira sala, que ultrapassa a dimensão da erudição clássica. Na Iconologia de Cesare Ripa, a iconografia da Anima ragionevole e beata é representada com o rosto coberto por um «finíssimo e transparente véu». ${ }^{49}$ Desta forma,

boschi / di nuova fronda si veste che in altro albero ha il seme / e i lisci tronchi circonda di gialle sue bacche, / tale su l'ìlice nera sembrava dell'oro la fronda, / così crepitava al vento lieve la lamina. / Enea in fretta la prende e la stacca bramoso / mentre quella esitava e la reca nell'antro all'indovina Sibilla.

49 Ripa, C. (1603). Iconologia. Roma: L. Facii: «Anima ragionevole e beata: Donzella gratiosissima, haverà il volto coperto con un finissimo, e trasparente velo [...] Benché l'anima, come si dice da Teologi, sia sustanza incorporea, immortale, si rappresenta nondimeno in quel miglior modo, che l'huomo legato à quei sensi corporei con l'imaginatione, la può comprendere. Si dipinge donzella gratiosissima, per esser fatta dal Creatore, che è fonte d'ogni bellezza, per dinotare che ella è, come dice S.Agostino nel libr. de definit. anim. sustanza invisibile a gl'occhi 
a figura alegórica «apesar da alma [...] seja substância incorpórea, a representa da melhor maneira».50 $\mathrm{O}$ atributo do finíssimo véu posto sobre os olhos associa à profecia clássica da fundação do império romano a dimensão do império da fé católica, relacionando-se com a função simbólica e política da instituição patriarcal. O escolhido, isto é, o eleito que poderá fundar e governar este novo império, unirá em si o destino de Eneias e as qualidades do Sábio Cristão.

Mais uma vez, os escritos do padre Rafael Bluteau reverberam no programa iconográfico da Biblioteca Joanina. Simultaneamente ao projeto do edifício, o erudito padre teatino apresentava em Lisboa as Prosas Academicas, logicas, fysicas, metafysicas, politicas, cosmograficas, jurisconsultas, e theologicas, demonstrativas das virtudes, e prerrogativas do Sabio Christão e manifestadas em sete liçoens na Academia do Conde de Ericeira D. Francisco Xavier de Menezes..$^{51}$ As «lições» foram proferidas entre 1717 e 1719 e publicadas, junto com outros textos da sua autoria, em 1727-1728: exatamente durante o arco cronológico da fundação, construção e decoração da biblioteca de Coimbra. ${ }^{52}$

Nas Prosas Academicas, Rafael Bluteau ilustrou as qualidades necessárias para a conquista progressiva da sabedoria até alcançar o estado angélico, próprio dos homens que se tornam intermediários entre a

humani, e forma sustantiale del corpo nel quale ella non è evidente, salvo che per certe attioni esteriori si comprende [...]». Ibidem.

51 Bluteau, R. (1727-1728). Prosas portuguezas recitadas em differentes congressos académicos pelo padre D. Rafael Bluteau, clérigo regular, doutor na Sagrada Theologia, pregador da rainha de Grãa Bretanha, Henriqueta Maria da França, qualificador do Santo Officio no Sagrado Tribunal da Inquisição de Lisboa, e Académico da Academia Real. Parte segunda. Lisboa Occidental : Na Officina de Joseph Antonio da Sylva, II.

52 Ibidem. O texto é dividido nos seguintes temas: «Com a sua lógica, o Sábio Christão sabe tirar proveitosas consequências; Com a sua fysica, o Sábio Christão logra huma discreta independência; Com a sua metafysica, o Sábio Christão he hum admirável abstracto do commum dos homens; Com a sua política, o Sábio Christão se accredita no governo de si próprio; Com a sua cosmografia, o Sábio Christão he huma viva Universidade do Universo; Com a sua jurispudencia, o Sábio Christão se faz feliz, e glorioso observador da Ley de Deos; Com a sua Theologia, o Sábio Christão dá vários documentos para a vida temporal, e eterna». 
terra e o céu. O Sábio Cristão reúne em si «virtudes e prerrogativas» específicas que não excluem o conhecimento proporcionado pela filosofia natural, pois «o Sábio Christão olha para o Mundo como um livro aberto [...] e contempla a sciencia do nosso saber e o Mundo como vastissima e numerosissima livraria». A descrição coincide com a organização do espaço da Biblioteca Joanina e o programa iconográfico corresponde à exortação do teatino: «Corra o Sábio Cristão toda a esfera do saber, faça a sua curiosidade o gyro de todas as artes e faculdades, seja o seu entendimento encyclopedia viva de todas as disciplinas e sciencias, mas no meyo deste scientifico circulo haja sempre polo fixo, centro imóvel para a observação da Ley Divina». ${ }^{53}$

Estabelece-se assim uma clara identidade entre as afirmações de Rafael Bluteau e a pintura da terceira sala que permite atribuir a elaboração do programa iconográfico da Biblioteca Joanina ao padre teatino e ao contexto cultural da corte joanina e da Academia liderada pelo conde de Ericeira, antecedente da Real Academia de História fundada em 1720.

Desde a entrada, e ao longo do percurso, o retrato do rei D. João $V$ indica a direção da conquista. Cada sala constrói progressivamente a finalidade última da aquisição da sabedoria, até se chegar à terceira sala onde o brasão da faculdade de Teologia se sobrepõe ao da Casa Real que, por sua vez, coroa o retrato de corpo inteiro de D. João V [fig. 10].

53 Almeida, C. Marques de (1996). O elogio do intelectual: a figura do "Sabio Cristão" nas prosas portuguesas de D. Rafael Bluteau. Dissertação de mestrado. Lisboa : Universidade Nova, 233. 


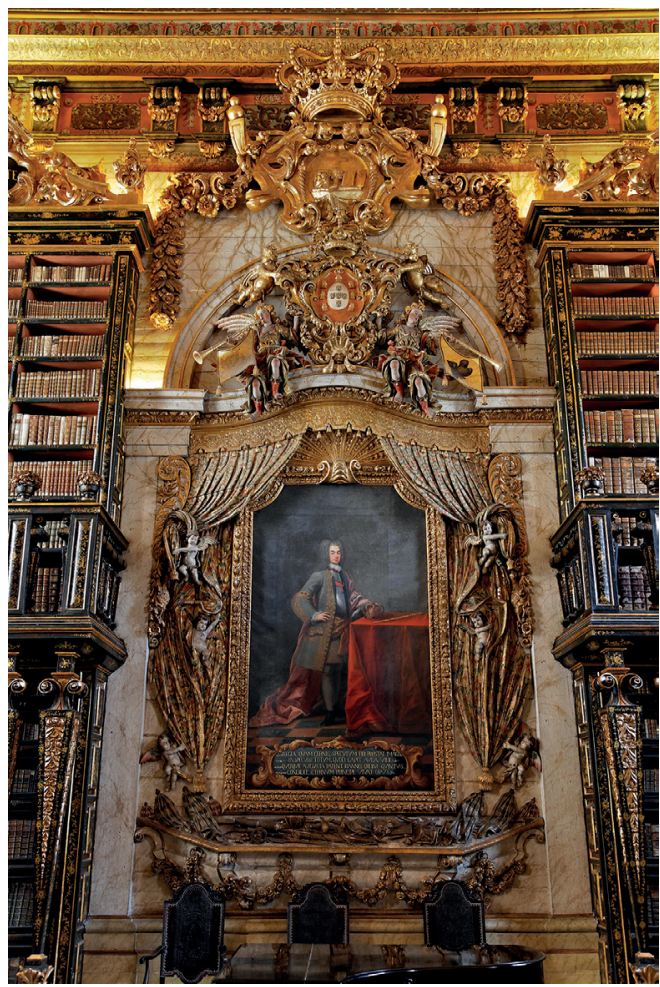

Fig. 10

Giorgio Domenico Duprà - Retrato de D. João V, Biblioteca Joanina, c. 1725

Finalmente o significado desvela-se integralmente: o rei é retrato vivente do destino e da ação do Sabio Cristão, fundador da nova Lisboa ocidental, como capital imperial e patriarcal segundo o modelo de Roma imperial e pontifícia. D. João V é o "eleito", a cujos pés o estudante depõe as armas da sua conquista finalmente alcançada [fig. 5].

Chegado ao fim do seu percurso, em harmonia com o significado simbólico representado pela quadratura nos três tetos, o estudante alcança a coroa de louros da vitória, pois conquistou o conteúdo integral da própria Biblioteca. O cartouche pintado debaixo do retrato de D. João V, ao nível do seu olhar, confirma-o: 
O retrato régio que contemplas está na tua frente como um espelho: nesse espelho vês tudo o que este palácio contém. E tudo o que de majestoso ostenta realizou-o João Quinto. Viva eterna a obra juntamente com o príncipe. ${ }^{54}$

Retornam os jogos de espelhos: finalmente o estudante pode-se rever na figura do monarca. Alcançando em si «as qualidades e prerrogativas» do Sábio Cristão, ele pode igualá-lo como imagem reflexa do rei e de todo o conhecimento contido na Biblioteca, em função da afirmação do poder imperial e da religião católica nos domínios lusitanos.

\section{O mundo artístico em volta da Biblioteca:}

\section{a arquitetura}

No contexto das dinâmicas culturais e artísticas descritas, algumas considerações podem ser avançadas em relação aos arquitetos envolvidos e, sobretudo, à organização e condução do estaleiro da Biblioteca Joanina. Como foi antes referido, a primeira ideia de construir o edifício «sem muita despesa» transformou-se num projeto ambicioso. Os trabalhos começaram em abril de 1717 sem nunca parar até ao acabamento da obra. ${ }^{55} \mathrm{Em}$ coerência com o interesse régio, a idealização do edifício partiu, a meu ver, dos arquitetos e engenheiros militares da corte joanina. Vale a pena lembrar que, em 17 de novembro de 1717, lançou-se também a primeira pedra da basílica de Mafra, cujo projeto estava sob a responsabilidade de João Frederico Ludovice. A primeira pedra da Biblioteca da Universidade de Coimbra foi lançada em 17 de julho do mesmo ano. A conceção da planta tripartida, através de dois arcos, e as janelas abertas para oriente e ocidente encontra-se descrita no tratado do padre Claudio

54 Ferrão (2015-2016), 70.

55 Ferrão (1993). 
Clemens Musei sive Bibliothecae, cujo livro III se abre com uma similitude entre «ars bellica, et libraria». ${ }^{56}$ Porém, é preciso considerar também que o Peregrino Instruído. Modo com que se deve informar todo o sugeito, que fizer giro, pela Europa, e mais partes do Mundo. Mandado fazer na occazião, que S. Mag.de o Sr. Rey D. João o quinto esteve para hir incognito, ver as Cortes Estrangeiras, ${ }^{57}$ escrito pelo padre Manuel Caetano de Sousa para a projetada viagem europeia do jovem monarca, incluía também adquirir todo o conhecimento possível sobre as bibliotecas. Entre as perguntas elencadas no parágrafo «o Estado Moral a que reduzimos tudo o que depende da indústria humana», em cada cidade o jovem monarca devia tomar conhecimento sobre: «[...] que Universidade ou Estudos públicos? Que Livrarias públicas? [...] Que Theatros? Que Passeos? Que Palácios? Que livrarias insignes de Particulares?». ${ }^{58} \mathrm{O}$ périplo europeu previa sair de Portugal diretamente para a Flandres. Depois, passar para Inglaterra, percorrer Alemanha, até chegar em Veneza para o Carnaval, em Nápoles durante a Quaresma, em Roma da Pascoa até o Corpus Dominis, ficar depois dois meses em Florença, chegar a Turim, ir a Paris e regressar através de Catalunha, Madrid e Andaluzia até entrar em Portugal. Em Itália, D. João V demoraria um ano; outro ano serviria para conhecer os outros países incluídos no "grand tour" de conhecimento, vocacionado também para contratar artistas e artífices. ${ }^{59}$

O possível envolvimento de Ludovice na formulação da primeira planta não exclui uma autoria múltipla do projeto, pois nos anos em que se construiu o corpo do edifício, em Lisboa a atividade projetual

56 Clemans, C. (1634). Musei sive Bibliothecae cura. Lugduni: sumptibus lacobi Prost, 448. O livro IV é dedicado à descrição da biblioteca do palácio-convento do Escorial.

57 Buescu, A. I. (2000). O “Peregrino Instruído". Viagem e poder na Europa setecentista. In Ead., Memória e Poder. Ensaios de História cultural (séculos XV-XVIII). Lisboa : Edições Cosmos, 111-170.

58 Ivi, 126-127.

59 Raggi (2014); Raggi (2017). L'effervescenza culturale... 
estava a ser intensíssima tocando o cume com a chegada de Filippo Juvarra de janeiro a julho de 1719.

O portal da Biblioteca Joanina e o sumptuoso brasão por cima da arquitrave representam os únicos elementos monumentais do singelo exterior do edifício. Em 1719, trabalhou-se nas colunas do portal. A primeira chegou em 20 de julho de $1719,{ }^{60}$ isto é, poucos dias depois do regresso para Itália do arquiteto italiano. $O$ transporte das pedras foi atribulado, tal como o levantamento das colunas e pedrarias que comportou riscos e dificuldades. ${ }^{61}$ Nesta situação destacou-se, pela capacidade de dirigir as operações, o entalhador Gaspar Ferreira, que substituiu nesta função o pedreiro João Carvalho Ferreira que tinha assinado o ajuste da empreitada em 1717.62 Para ultrapassar as dificuldades surgidas no transporte e levantamento das colunas, a organização do estaleiro beneficiou das despesas feitas em 1720 para «cordas grossas, pranchas, paus dos mastros e sarilho». ${ }^{63} \mathrm{Du}-$ rante os meses da sua estada em Lisboa, Filippo Juvarra ocupara-se da organização das equipas de trabalho (pedreiros, escultores) e da maquinaria necessária para o grandioso estaleiro do palácio real, basílica e palácio patriarcais no sítio de Buenos Aires. Documentos recém-publicados permitem comprovar, também, a sua intervenção no projeto e na organização do estaleiro de Mafra. ${ }^{64}$ Por isso, a efervescência vivida em Lisboa pôde influenciar o projeto em andamento da Biblioteca da Universidade. O portal e, sobretudo, o sumptuoso brasão esculpido em pedra podem ter sido derivados de esquiços

60 Ferrão (1993), 97.

61 Ferrão (1993), 96-97.

62 Ferrão (1993), 95, 98-99 e nota n. 56.

63 Ferrão (1993), 98.

64 Sobre as longas «conversas de arquitetura» trocadas com D. João V; sobre o pedido de contratação de 500 mestres e oficiais da região italiana de Como, tradicionalmente especializados na construção de palácios e igrejas régias e na escultura das ordens arquitetónicas; sobre o envolvimento e Juvarra no projeto do complexo de Mafra veja-se Raggi (2017). Filippo Juvarra in Portogallo... 
do arquiteto italiano ou, como mostrarei abaixo, de outros modelos europeus. ${ }^{65} \mathrm{O}$ desenho da cenográfica escadaria de Minerva revela, a meu ver, a influência da mudança de paradigma introduzida por Filippo Juvarra em planear a nova Lisboa. ${ }^{66} \mathrm{Em} 1723$, ano do início da construção dos alicerces da escadaria, o monarca ainda mantinha a intenção de arrancar com o grande estaleiro de Buenos Aires, projetado em 1719, onde o novo palácio real se debruçava sobre o Tejo através de um cenográfico sistema de escadarias, rampas e terrapieni com fontes monumentais e eixos visuais sobre o rio, a barra, o oceano e, também, sobre a cidade e a Ribeira [fig. 11]. ${ }^{67}$

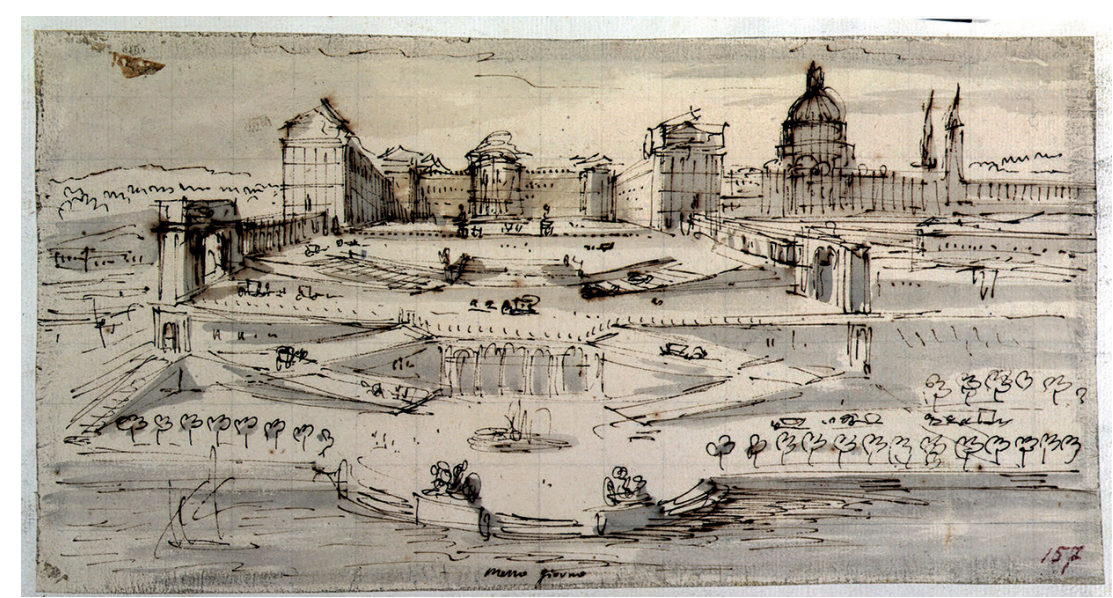

Fig. 11

Filippo Juvarra - Ideia para o segundo projeto do palácio real, basílica e palácio patriarcais no sítio de Buenos Aires, 1719.

Torino, Palazzo Madama, inv. 1859/DS

65 O mais recente ensaio relativo a Claude Laprade não the atribui esculturas em pedra depois dos primeiros anos de Setecentos, porém a sua possível participação merece ser aprofundada em estudos futuros. Veja-se Ferreira, S. (2015). Claude Laprade: um escultor provençal na Lisboa de Setecentos. Cadernos do Arquivo Municipal, 3, 149-178.

66 Rossa, W. (2017). Juvarra: cenografia e urbanística para uma capital do lluminismo. Estudos Italianos em Portugal, 12, 271-294.

67 Raggi, G. (2017). Dalla scuola romana di Carlo Fontana ai circuiti europei dei Galli Bibiena: architetti italiani in Portogallo nel XVIII secolo. Estudos Italianos em Portugal, 12, 295-324. Raggi, G. (2018). A cidade do rei... 
Existe um certo paralelismo entre a forma em " $U$ " do pátio da Universidade de Coimbra, que domina a cidade do alto, abre-se ao horizonte e debruça-se sobre o rio Mondego com a visão cenográfica do palácio real, idealizado por Filippo Juvarra.

Os documentos recém-publicados testemunham, também, a inexistência de uma relação antagónica entre Filippo Juvarra e João Frederico Ludovice. A partir da estada do arquiteto italiano em 1719, os estaleiros dos projetos planificados por D. João $V$ adotaram a organização vigente na escola romana de Carlo Fontana. $\mathrm{O}$ arquiteto principal projetava, concebendo no seu conjunto a obra, sendo coadjuvado pelo(s) arquiteto(s) que transformava(m) o projeto em plantas e alçados executivos, coordenando os mestres-de-obras que lideravam equipas de acerca de 25 oficiais, ativas simultaneamente em diferentes tarefas de execução das obras. ${ }^{68}$ Este modus operandi explica porque, na maioria dos casos, plantas executivas e documentos apontam principalmente os nomes de quem dirigiu e realizou os trabalhos in loco.

Em Coimbra, o mestre Gaspar Ferreira destacou-se como arquiteto local na circunstância do complexo levantamento do portal monumental da Biblioteca. Esta função é comprovada, também, pelo seu papel por altura da construção da torre da Universidade, em 1728$1729 .{ }^{69}$ A planta fornecida por Gaspar Ferreira foi analisada pelo Deputado da Mesa da Consciência e Ordem, D. Lázaro Leitão, cónego da igreja patriarcal e secretário do marquês de Fontes durante a embaixada extraordinária a Roma (1712-1718). A resolução do rei foi de a apresentar aos «Arquitetos desta Corte e porque a não aprovaram, se mandou fazer outra pelo Arquiteto Romano Antonio Canevari».70 Sem dúvida, João Frederico Ludovice estava incluído entre os arqui-

68 Raggi, G. (no prelo). Repensando Mafra.

69 Pimentel, A. (2007). Antonio Canevari e a torre da Universidade de Coimbra. In VII Colóquio Luso-Brasileiro.

70 ANTT, Mesa da Consciência e Ordens, Universidade de Coimbra, maço 60, fls. S.n. 
tetos de corte, mas a resolução de $\mathrm{D}$. João $\mathrm{V}$ comprova que, no que dizia respeito às arquiteturas régias de maior importância simbólica, a idealização era atribuída a arquitetos e artistas italianos, quando presentes em Lisboa. A encomenda ao ebanista italiano Francesco Realdino dos bufetes da Biblioteca Joanina ${ }^{71}$ confirma ulteriormente a estreita conexão com a atmosfera cultural vivida na corte joanina e o interesse régio de envolver artistas estrangeiros.

Neste contexto, e apesar da prioridade dada aos modelos romanos e italianos, a paixão pela arquitetura de $D$. João $V$ estendia-se às obras dos principais arquitetos europeus. De facto, no exercício crítico de encontrar possíveis modelos para o portal monumental da Biblioteca Joanina, sobressai, a meu ver, a relação com as obras de Johann Bernard Fischer von Erlach (Graz 1656 - Viena 1723) e do seu filho Joseph Emanuel (Viena 1693-1742). Tendo em conta os estudos recentes sobre o impacto na corte lusitana da cultura de Maria Ana de Áustria e considerando a participação ativa da rainha na definição das novas residências reais, as relações entre a efervescência joanina e os projetos imperiais de Viena tornam-se possíveis e fascinantes. ${ }^{72}$ $\mathrm{Na}$ arquitetura de Johann Bernhard Fischer von Erlach é recorrente o uso de duplas colunas para ladearem aberturas em arco (portais ou janelas monumentais) e sustentarem, ao centro do entablamento, ricos brasões. ${ }^{73}$ Além disso, em Viena, o projeto da Hofbibliothek tinha sido encomendado ao arquiteto de corte Johann Philipp Quentzer desde 1681 pelo pai da rainha de Portugal, o imperador Leopoldo I. Por causa do assédio turco de 1683 e da guerra de sucessão espanhola (1702-1714), o projeto foi retomado pelo irmão da rainha, o imperador Carlos VI. Entre 1721 e 1730 a Hofbibliothek foi construída

71 Ferrão (1993),105.

72 Raggi, G. (2017). Una lunga passione per l'opera in Portogallo...; Raggi. G. (2018). O espaço teatral na corte de D. João V...

73 Gordon Dotson, E. (2012). Johann Bernhard Foscher von Erlach. Architecture as Theater in the Baroque era. New Haven: Yale University Press; Kreul, A. (2006). Johan Bernhard Ficher von Erlach, Regie der relation. Salzburg-Munchen : Verlag Anton Pustet. 
e decorada. O projeto de Johann Bernhard, elaborado a partir de 1716, foi levado a cabo pelo filho de Joseph Emanuel Fischer von Erlach. Em 1728, a Biblioteca imperial estava concluída, podendo dar-se início à pintura dos frescos. ${ }^{74}$

A coincidência cronológica entre os projetos da biblioteca imperial de Viena e da biblioteca de Coimbra pode ter proporcionado aos arquitetos portugueses modelos e ideias de Johann Bernhard Ficher von Erlach. A qualidade arquitetónico-compositiva do portal é patente, embora a execução deixe transparecer incongruências de proporções na parte superior. A possibilidade de se ter elaborado um desenho, no âmbito da corte joanina, a partir dos modelos de Fischer von Erlach é plausível à luz da reconstrução histórica proposta neste artigo. Outro elemento de contato entre Viena, Lisboa e Coimbra encontra-se, a meu ver, na tipologia das estantes, que merecem ser estudadas a partir de uma visão comparada com as da Hofbibliothek. De facto, a relação entre a biblioteca imperial de Carlos VI e as bibliotecas joaninas não se limita à de Coimbra. Torna-se ainda mais evidente em relação à planta da biblioteca do palácio-convento de Mafra. É interessante lembrar que o programa iconográfico dos frescos na biblioteca de Viena, pintados por Daniel Grans entre 1728 e 1730, foi elaborado pelo erudito Conrad Adolph von Albrecht. Por volta de 1730, ele foi escolhido por Carlos VI como residente imperial em Lisboa, onde chegou em 1734 e permaneceu até 1737. Especialista em arquitetura e cultura clássica, em 1735, visitou o estaleiro de Mafra com amplo mandado do rei $\mathrm{D}$. João $\mathrm{V}$ para averiguar as plantas, o progresso das obras e a conformidade estilística com as regras da arquitetura. ${ }^{75}$ Por isso, os projetos e a construção da Hofbibliothek de Viena e das duas bibliotecas projetadas de raiz em época joanina

74 Kreul (2006).

75 Sommer- Mathis, A; Raggi, G. (no prelo). Giuseppe Zignoni and Conrad Adolph von Albrecht, Imperial representatives at the Portuguese Court: between diplomacy, music and theatre. Wien : Hollitzer. 
(Coimbra e Mafra) devem ser considerados, a meu ver, como processos simultâneos, em que trocas e osmoses foram recíprocas e frutuosas.

\section{O mundo artístico em volta da Biblioteca:}

a pintura de quadratura

A escolha da quadratura para decorar os tetos da Biblioteca conecta-se com o processo de renovação cultural impulsionado por D. João V desde os primeiros anos do seu reinado, tendo como momento catalisador as celebrações do seu casamento com a arquiduquesa D. Maria Ana de Áustria. Nesta ocasião, o pintor florentino Vincenzo Bacherelli encontrou o momento de maior promoção da sua arte na dupla vertente da quadratura e da cenografia. Como foi acima referido, a quadratura fundamenta-se no conhecimento das regras da perspetiva e das ordens arquitetónicas, envolvendo a pintura dos cenários também. Os quadraturistas bolonheses, cuja obra em Florença deu origem à escola de quadratura toscana, estavam ativos quer no campo da pintura a fresco, quer no do teatro e da cenografia. A família Bibiena representou a síntese desta tradição exportada para toda a Europa do século XVIII graças ao sucesso da ópera italiana. ${ }^{76}$ Depois de Bolonha, centro de formação dos artistas na Academia Clementina, Viena constituía o principal centro europeu de produção de óperas italianas desde o século XVII e, em particular, durante a primeira metade do século XVIII. ${ }^{77}$ Por isso, em 1708 , D. João V quis mandar representar uma «ópera italiana» ${ }^{78}$ durante as festas nupciais. Em estudos recentes, identifiquei esta

76 Bentini, J., Lenzi, D. (2000). I Bibiena. Una famiglia europea. Venezia : Marsilio.

77 Sommer-Mathis, A (2017).The imperial court theater in Vienna from Burnacini to Galli Bibiena. Music in Art, XLII, 1-2, 11-37.

78 HHStA, Familienakten, kart. 39, 39-1, f. 165: «non si pensa ad altro che a affrettare con ogni diligenza li preparativi per il ricevimento di S. M.tà, e fra varie feste, ed alegrie, che si sono ideate per la celebrazione delle Reali nozze, pretende di far qui rappresentare una opera italiana». 
primeira ópera com o «drama em música» representado na grande máquina de fogos de artifícios criada por Carlos Gimac no Terreiro do Paço. ${ }^{79} \mathrm{Na}$ realidade, não se tratava de uma simples estrutura pirotécnica, mas de um monumental teatro de arquitetura efémera que incluía o palácio de Vénus, o vulcão Etna, um «teatro» montado adequadamente para as mudanças de cenas e um jardim, a partir do qual, chegando ao fim a representação em música, se atou o incêndio despoletando o jogo pirotécnico final. ${ }^{80}$ Vincenzo Bacherelli ocupou-se da estrutura do teatro, tendo sido encarregado de pintar as salas do palácio real da Ribeira, renovado antes da chegada da rainha. Por isso, a arte da quadratura associa-se não só à arquitetura, mas também ao rico mundo artístico da ópera italiana. Durante os vinte anos vividos em Lisboa, Bacherelli difundiu o gosto pela pintura da quadratura e contribuiu também para o processo de introdução da ópera em Portugal e das artes relacionadas com a encenação de melodramas [fig. 12].

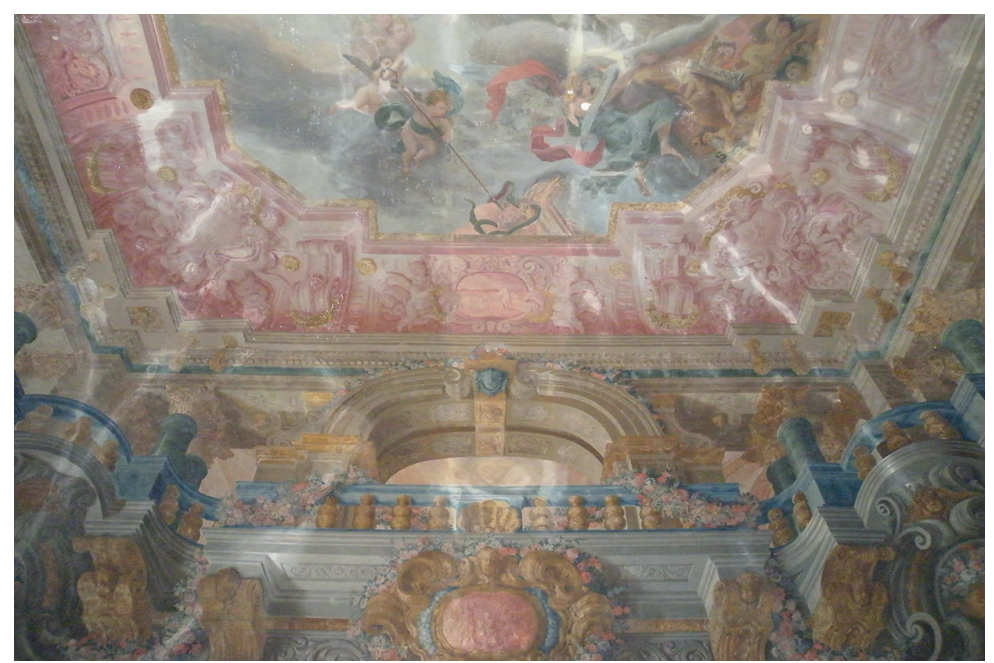

Fig. 12

Vincenzo Bacherelli - Quadratura, teto da portaria de São Vicente de Fora, 1710. Foto da autora

79 Raggi (2018). O espaço teatral na corte de D. João V...

80 lbidem. 
O artista italiano trabalhou para D. João $\mathrm{V}$ e para as mais importantes elites da corte e do reino joanino. Encomendas para pintar espaços religiosos, palácios, quintas da principal nobreza, além da atividade de cenógrafo para as principais famílias e ordens religiosas, asseguraram o sucesso da sua arte e caraterizaram o gosto dos mesmos protagonistas envolvidos no projeto da Biblioteca da Universidade de Coimbra.

Quando os tetos do edifício estavam prontos para serem pintados, Vincenzo Bacherelli já tinha regressado a Florença. A escolha recaiu sobre pintores de Lisboa, formados no grupo de quadraturistas portugueses que aprenderam com o pintor italiano. António Simões Ribeiro e Vicente Nunes souberam interpretar o programa iconográfico previsto, dando um contributo fundamental para que a conquista da sabedoria adquirisse o sentido espacial credível e verosímil, necessário à transmissão do significado metafórico e simbólico acima descrito.

António Simões Ribeiro e Vicente Nunes realizaram as pinturas entre agosto de 1723 e março de $1724 .{ }^{81}$ Logo que a acabaram, os dois artistas pediram ao rei $D$. João $V$ uma mercê de vinte moedas de ouro, justificando-a com o valor artístico da idealização da obra. No contexto português, a valorização económica do momento da invenção é rara e a carta escrita por António Simões Ribeiro testemunha as novas dinâmicas artístico-culturais que motivaram o rei e a corte durante os anos da 'efervescência joanina' e que se refletiam, também, na refinada cultura da Academia reunida no seu palácio pelo $4^{\circ}$ conde de Ericeira, ${ }^{82}$ em cujo âmbito o programa iconográfico foi elaborado.

Desde o ajuste da obra estava previsto recompensar os quadraturistas pela sua atividade criativa, pois a quadratura devia ser

81 Raggi (2018). Architettura versus Pittura..., 304.

82 Kantor, I (2004). Esquecidos e Renascidos. Historiografia acadêmica luso-americana (1724-1759). São Paulo : Hucitec; Salvador : Centro de Estudos Baianos, 30; Palma-Ferreira, J (1982). Academias Literárias dos séculos XVII e XVIII. Lisboa : Biblioteca Nacional. 
«singular» e a melhor «que no reino se pode fazer». A memória do modus operandi de Vincenzo Bacherelli, que ganhara uma verdadeira fortuna graças à sua atividade de pintor e aos investimentos feitos no seio da comunidade italiana de banqueiros, ecoa nas entrelinhas do documento:

Estavam ajustados com esta Universidade para haver de Ihe pintarem as três Casas da Livraria, a saber: de teto e cimalha cada Caza pelo preço de 600.000 reais, as quais se obrigavam a pintar da forma seguinte:

Pintar o teto de cada hua das Cazas de sua planta diferente na forma que apresentaram pelos riscos os quais se aprovam e deve ser a dita pintura de perspetiva e feita com o maior primor da arte que seja a contento da Universidade e no tempo que com os sobreditos se ajustou a obra de sorte que há de ser a dita pintura de perspetiva singular e o milhor que no reino se pode fazer. A simalha há de ser pintada de pintura selleta farta de ouro e dourado tudo o que for talha e todos os remates em forma que fique com toda a perfeição e gal hardia. Allem dos ditos 600.000 reia para cada Caza satisfará a Universidade esta jornada à Universidade e justo preço dos ditos três riscos. E os sobreditos serão obrigados a virem athé quinze do mês de Julho deste presente ano principiar a obra e continuarão emthé se acabar. ${ }^{83}$

Após a execução da obra, António Simões Ribeiro escreveu à Mesa da Consciência e Ordens em nome, também, de Vicente Nunes, sobre a penúria da compensação recebida:

Diz António Simões Pintor m.or nesta cid.e de Lxa occ.al que elle supp.e e Vicente Nunes dourador rematarão a obra da pintura dos tectos e simalhas das casas da Livraria nova da Un.de de Coimbra em preço e q.tia de seis centos milreis cada hua das d.tas cazas, fazendo a da pintura de

83 Garcia, P. (1923). Artistas de Coimbra. Documentos para as suas biografias. Coimbra, 295-299. O ajuste foi assinado em 22 de junho de 1723. 
prospectiva com todo o primor da arte e com effeito tanto satisfez o supp.e a sua obrig.am; $q$ ficarão as d.as Cazas com toda admiração e magnificência em forma q senão achará facilm.te não só neste Reyno, mas em toda a Europa, Caza mais magestosa e magnifica; porem com tanto prejuízo do supp.e q gastando na da obra o tempo de Agosto de 723 athé fim de M.ço deste prez.te anno de 724 com seis ou sete officiaes cada dia, Ihe não chegou o dro p. a acabar de pagar os dias de todos a os offes perdindo de mais os seus jornais, q estando nesta Corte e dormindo em sua caza lucra por dia além do seu comer doze tostões, e vejo o supp.e a perder mais de trezentos milreis e reprezentando todo este prejuízo à Meza da fazenda da da Un.de conseguiu som.te q o R.or e Deputados della conhecessem a perda q o supp.e tive, mas não lhe deferirão com o remédio de lhe darem algum donativo, com q pudesse recompensar a sua perda ou p.te della com o fundam.to de que não tinhão jurisdição $p^{a}$ fazer donativos e m.ces; e som.te Ihe derão quarenta e outo milrs pelas três plantas $q$ fez $p^{a}$ a da obra conforme se estipulou e contractou na escriptura de rematação porem satisfizeraolhe m.to limitadam.te as d.as plantas em $q$ o supp.e gastou m.tos dias, $e$ noutes, e sem duvida merecia m.to bem Ihe dessem vinte moedas de ouro pelas tais plantas; e porq o supp.e he homem pobre e se acha com m.tas obrigações e com a perda, q experimentou fica totalm.te destruído, se Va. Mag.de não for servido por equid.e conceder-Ihe provisão p. a a Meza da fazenda da da Un.de dé ao supp.e por graça e m.e hua tal porção q corresponda â grandeza da obra e ao damno q o supp.e padeceu, e lhe satisfaça com outra tanta q.tia o custo e justo valor das d.as plantas ${ }^{84}$.

O requerimento dirigido ao rei $D$. João $V$ tocava os pontos nevrálgicos da política artística promovida pelo monarca nos primeiros anos Vinte: os tetos da Biblioteca ficaram «com toda admiração e

84 AUC, IV-1ª.E-1-25, Bibliotheca, Despesas de Limpeza séc. XVIII, Obras, Relatório 1831, fls. s.n. 
magnificência em forma que senão achará facilmente não só neste Reyno, mas em toda a Europa casa mais Magestosa e Magnifica». O resultado justificava a contestação à Universidade de ter pago somente «quarenta e outo milreis pelas três plantas que fez para a dita obra» sem Ihe reconhecer o trabalho de invenção no qual «gastou muitos dias, e noites, e sem dúvida merecia muito bem Ihe dessem vinte moedas de ouro pelas tais plantas». ${ }^{85} \mathrm{O}$ pintor recebeu a metade do valor pedido e a decisão do rei foi rubricada pelo poderoso cónego da patriarcal padre Lázaro Leitão, secretário do marquês de Fontes durante a sua embaixada extraordinária em Roma (1712-1718).

A insistência sobre o valor da arte e o exercício da invenção criativa destaca este episódio por entre o panorama corrente das relações entre artistas e encomendadores portugueses. Os dois artistas lusitanos avançaram o pedido de recompensa apelando aos princípios que caraterizavam as relações entre os artistas estrangeiros, nomeadamente italianos, e a corte portuguesa. Por exemplo, Vincenzo Bacherelli cobrava pagamentos muito altos, chegando a deixar a meio trabalhos mal retribuídos. Filippo Juvarra distinguiu-se entre todos os artistas italianos, pois foi convidado sob a licença do rei de Sardenha e recompensado lautamente com donativos, joias e a mercê da Ordem de Cristo, recebida em julho de 1719, antes de regressar para Itália, com dispensa direta de D. João V para não se proceder ao processo obrigatório sobre a limpeza de sangue.

A maneira de António Simões Ribeiro e Vicente Nunes justificarem o pedido de «vinte moedas de ouro» encontra a sua explicação face ao contexto em que foi elaborado e encomendado o programa simbólico-iconográfico da biblioteca de Coimbra. Este correspondeu ao auge da política artística joanina e da abertura da corte portuguesa aos modelos de vida cortesã europeia, onde a função política das artes constituía um dos principais instrumentos de afirmação do

85 Ibidem. 
poder das monarquias. Importa também lembrar que a realização das quadraturas na Biblioteca Joanina se situa, cronologicamente, entre a fundação da Academia Real de História (1720), decorrente da já citada Academia do conde de Ericeira, e a instituição da Academia dos Esquecidos em Salvador da Bahia (entre 1724 e 1725) pelo vice-rei Vasco Fernandes César de Menezes. ${ }^{86} \mathrm{O}$ propósito de escrever a história política, eclesiástica, natural e militar do Brasil seguia as finalidades da Academia Real de História. A realidade americana tornava-se, metaforicamente, livro a colocar nas estantes da primeira sala da Biblioteca da Universidade de Coimbra, centro de irradiação da sabedoria do Sábio Cristão, por ser a sede onde se formavam, também, as elites destinadas à gestão do império.

\section{0 "silêncio" da Biblioteca Joanina}

Como é conhecido, à construção do edifício da Biblioteca Joanina não correspondeu o preenchimento das estantes e a abertura pública da biblioteca como anunciado manifestamente pelo programa exposto no edifício. As circunstâncias do impasse aguardam por ser entendidas mais aprofundadamente, quer em relação ao projeto educativo visualizado pelo programa iconográfico, quer, sobretudo, em comparação com o investimento na biblioteca das Régias Escolas de Mafra decidido por D. João V durante a interrupção das relações diplomáticas com a Santa Sé (1728-1732).$^{87}$ Seja como for, em janeiro de 1730, o secretário de Estado Diogo de Mendonça Corte Real comunicava ao reitor Francisco Carneiro de Figueiroa:

Sendo prezente a S. Mag.de que para ajustarse a compra dos livros que se tem mandado buscar a Holanda $\mathrm{p}^{\mathrm{a}}$ a Livraria dessa Un.de

86 Kantor, Esquecidos e Renascidos..., 89-165.

87 Abordo parcialmente este assunto no livro O projeto de D. João V... 
hé necessária m.ta mayor quanti de dinho do q. a que já se remeteu [...] me ordena [...] mande pôr prontos por hora ao menos seis mil cruzados [...] e recomenda [....] que do dinhro, que se for cobrando as rendas da Un.de procure separar o mais, que for possível $p^{a}$ a despeza de livros, a fim de que se possa comprar ao menos os mais preciosos $p^{a}$ huma livraria pubblica, e não fiquem inúteis as excessivas despezas, que se tem feito na matéria della. ${ }^{88}$

Em maio de 1741, os deputados da Mesa da Fazenda da Universidade pediram licença régia para «se fazerem algumas moradas de cazas [...] para acomodação dos lentes ou estudantes». Recebida a consulta através da Mesa da Consciência e Ordens, D. João V respondeu:

Fui servido resolver não ser conveniente a construção das cazas $p^{a}$ que pedíeis a da licença pella despeza que nella se faria [...] e que os sobejos que a Un.de tem se poderiaõ com faculdade minha aplicar em couza que possa servir ao seu ornato e grandeza, em que se compreende a livraria, que está muito no seu principio, sendo o pro objecto da mesma Un.de de que me pareceo avisarvos $p^{a}$ que assim o tinhais entendido. ${ }^{89}$

À magnificência da biblioteca devia corresponder a riqueza dos seus livros, como escrevera Bernardo de Brito Coelho em 1725.90 No intento de D. João V, o edifício constituía, simbólica e concretamente, o centro pulsante da Universidade. Em 1746-1748, a biblioteca continuava a carecer de livros. Possuía 6916 volumes, menos da metade dos 15.000 que se calculam constituíssem, por exemplo,

88 AUC, IV.1'a.E-1-1-17, Livros, acquisição de bibliotecas... (1710-1832), f. s.n.

89 AUC, IV-1a. D-3-2-20, Registo de Provisões, vol. 4 (1691-1744), fls. 385v-386r

90 Rodrigues (1990), 133. 
a biblioteca do colégio jesuíta de Salvador em $1759 .{ }^{91}$ O novo reitor D. Francisco da Anunciação escreveu à Mesa da Consciência e ordens evocando as mesmas motivações escritas pelo rei em 1741 e pedindo o dinheiro necessário para o efeito. As verbas destinadas à compra dos livros eram de tal maneira reduzidas que seriam precisos «muitos séculos» para formar uma «livraria completa e competente»:

Em 22 de Agosto de 1746 reprezentei a V. Mag. ${ }^{\text {de }}$ que a livraria publica $q$ com Real permissão de V. Mag. ${ }^{\text {de }}$ edificou esta Universid.e: se achava já com livros, e se devia fazer patente p.a o uso dos lentes, doutores, estudantes e de todos os curiosos, p.a o q era necessário constituir officiaes, $q$ tivessem cuidado da mesma livraria. Depois fiz pres.te a V. Mag. ${ }^{\text {de }} q$ o numero de livros, q tem a da livraria erão seis mil novecentos e deseseis, $e$ a consignação annual p.a o augmento dos livros cem mil reis. Agora novam.te ponho na prez.a de V. Mag. ${ }^{\text {de }}$ q na da livraria há m.ta falta de livros de todas as faculdades, e q a consignação de cem mil reis p.a o augm.to da mesma livraria he tão diminuta, $\mathbf{q}$ em $\mathbf{m}$.tos séculos se não formará livraria completa, e competente a huma Universid.e, que iguala, ou excede as maiores da Europa, e se viria a fazer inútil o dispêndio, q a mesma Universid.e fez na sumptuosidade, e grandeza das cazas da livraria, se esta não houvesse de encher-se de livros, cuja falta me tem requirido os lentes faça prezente a V. Mag. ${ }^{\text {de }}$; I Ihe peça se sirva V. Mag. de de deferir ao requerim.to de se por publica a livraria, e se crearem os officiaes, q aguardem, e cuidem da sua conservação, e que se digne V. Mag. ${ }^{\text {de }}$ de conceder lic. a p.a se proverem de livros as três cazas da livraria, fazendo-se esta despeza dos sobejos das rendas da Universid.e, não se faltando por esta cauza as obrigações impostas nas mesmas rendas. V. Mag. ${ }^{\text {de }}$ mandará o q for servido. Coimbra 20 de Julho de $1748 .{ }^{92}$

91 Leite, S. (2004). História da Companhia de Jesus no Brasil. Rio de Janeiro : Edições Petrobras, (1a ed. 1938-1950), vol. V, 216.

92 ANTT, Mesa da Consciência e Ordens, Universidade de Coimbra, maço 60, fl. s. n.: documento em "Sobre a conta q deu o Reytor da Universidade de Coimbra p. ${ }^{\text {a }}$ 
A relação enviada em 1746 dava conta da quantidade e distribuição dos livros, incluindo também os que não se encontravam in situ, isto é, no espaço físico da Biblioteca Joanina:

Na livraria da Univ.e se achão os volumes seguintes

Em Theologia e S. Padres 1229

Em Cânones 640

Em Leis 1855

Em Medicina 1305

Em Phylosophia 211

Em Mathematica 361

Historia Eclesiastica 170

Historia Secular 668

Latinidades 105

[total] 6544

Achão-se mais duzentos e noventa e nove volumes quase todos de quarto que se andão distribuindo por todas as Faculd.es a que pertecem 299 Achão-se mais doze tomos de Marca Mayor em q se contem o Atlas o Danubio, Anathomias, Ervas Flores 12

Achão se mais secenta e hum tomos de $=$ Acta Eruditorum $=e$ também = Caluor de Pace Eclesiastica 1 tom = e Rituale Eclesiasticum 2 tom $=\mathrm{Lu}$ dovic Ellies Dupin = Antiqua eclesia disceplina = Salmesius de Primatu Papae e por ultimo Molindo 4 tomos 61

\section{[total] 6916}

Todos estes assim o =Acta Eruditorum = como os mais $q$ a estes se seguem estão fechados em estante separada. ${ }^{93}$

se criar hum Bibliothecario com seu official p. a Livraria e se extinguirem outros officios - 16 de Janeiro de 1748".

93 lbidem. 
Apesar das dificuldades da constituição do acervo livresco e da abertura ao público da Biblioteca Joanina, o valor artístico-arquitetónico do edifício continuou a ser reconhecido. Mesmo na época pombalina, quando a volumetria disponível foi considerada demasiado reduzida e foi elaborado o plano de duplicação da biblioteca pelo arquiteto militar Guilherme D'Elsden, o interior teria sido preservado intacto. De facto, o corpo especular a erguer à direita da nova capela adotava a mesma planta da Biblioteca Joanina. Diversamente, o portal monumental teria sido completamente destruído e substituído por uma fachada mais comprida e austera. ${ }^{94}$ Por isso, a preservação da decoração interior não contemplava a reafirmação do significado simbólico do edifício como fortaleza da sabedoria a conquistar, anunciada desde o exterior do portal joanino. Os tempos haviam definitivamente mudado.

\section{Projetos de remodelação e restauro da quadratura nos séculos XIX-XX}

Em finais do século XIX, as pinturas de quadratura dos tetos da Biblioteca Joanina atraíram a atenção de António Augusto Gonçalves (1848-1932). No piso inferior da antiga livraria encontra-se um desenho em aguarela de sua autoria, agora retirado para digitalização e restauro da moldura, que, pela forma e pelas proporções, remete para os tetos da Biblioteca Joanina. Porém, a solução quadraturística é diferente e claramente inspirada no fresco de Andrea Pozzo da nave da igreja romana de Sant'Inácio, conhecida graças à gravura do tratado Perspetiva pictorum, et arquitectorum... [fig. 13].

94 Mora, M. (1993). Os projetos de remodelação do Paço das Escolas, ao tempo da reforma pombalina. In Dias, P. (Ed.), Actas do colóquio. A Universidade e a Arte (1290-1990). Coimbra : Universidade de Coimbra, 129-167; Trindade, L. (1998). A Reforma Pombalina. Monumentos, 8, 53-57. 


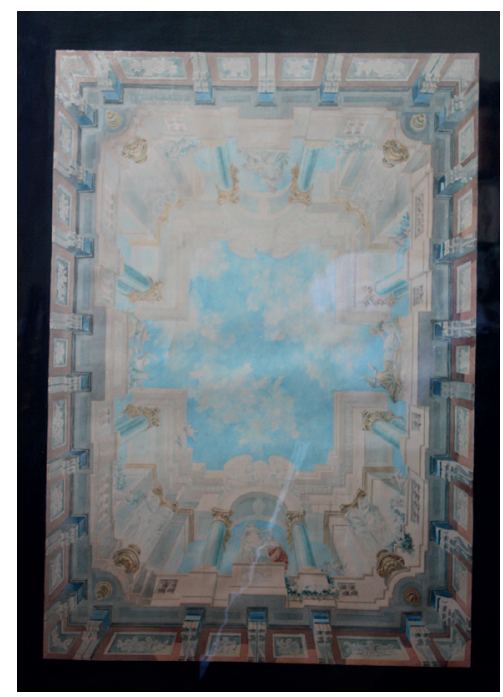

Fig. 13

António Augusto Gonçalves - Quadratura para um dos tetos da Biblioteca Joanina, Universidade de Coimbra. Foto de Vítor Murtinho

Noutro ambiente da Universidade encontra-se outra aguarela de dimensões parecidas, sempre de autoria de António Augusto Gonçalves, na qual uma baixa balaustrada, pintada em sottinsu, deixa aberto o espaço do céu para a representação de uma glória desenhada nos moldes do estilo romano de época barroca [fig. 14].

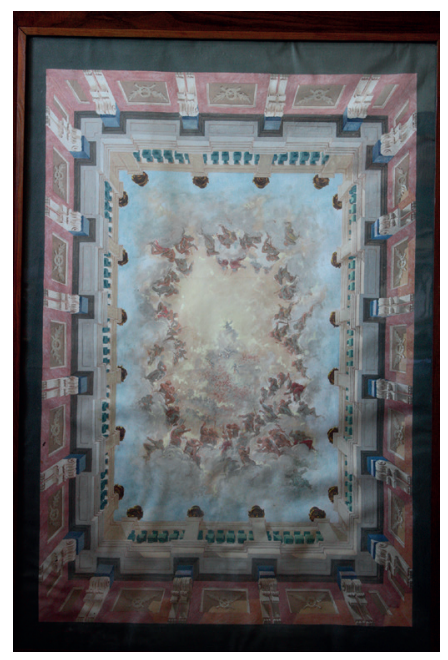

Fig. 14

António Augusto Gonçalves - Quadratura para um dos tetos da Biblioteca Joanina, Universidade de Coimbra. Foto de Vítor Murtinho 
É provável que, num futuro próximo, venha a encontrar-se um terceiro desenho, similar na técnica e dimensões aos outros dois, completando a série destinada aos tetos da Biblioteca Joanina.

Por enquanto, faltam informações sobre o motivo da realização destas aguarelas. Por um lado, podem ter sido exercícios de invenção perspética no âmbito do ensino do desenho lecionado por António Augusto Gonçalves: a construção exata da perspetiva, o uso correto da luz e da sombra para assinalar a relação com a posição de portas ou janelas reais demonstram o conhecimento académico da pintura de quadratura e de figuras em escorço dos séculos XVII e XVIII. Por outro lado, estas obras podem representar propostas para uma intervenção concreta. Caso, no futuro, se venha confirmar a intenção de restaurar os tetos da Biblioteca Joanina, as propostas apresentadas por António Augusto Gonçalves demonstrariam a perda da memória das dinâmicas artísticas luso-italianas da primeira metade do século XVIII.

A linguagem pictórica de António Simões Ribeiro fundava-se na tradição cenográfico-perspética bolonhesa, introduzida em Portugal através da lição de Vincenzo Bacherelli. Diversamente, os desenhos de António Augusto Gonçalves tornam patente a opção pela cultura romana de Seiscentos. Em conformidade com as categorias estilísticas que estavam a ser formuladas na segunda metade do século XIX, o estilo Barroco, antagónico ao Renascimento, reconhecia-se nas obras romanas do século XVII (Bernini, Borromini, Pietro da Cortona, Andrea Pozzo), enquanto a cultura artística barroca bolonhesa continuava numa fase de prolongado esquecimento.

Outros conceitos de restauro nortearam os trabalhos realizados entre 1931 e 1934. Em outubro de 1931, Henrique Gomes da Silva, diretor geral dos Edifícios e Monumentos Nacionais da Repartição Central de Lisboa, solicitou a Baltazar da Silva Castro, diretor dos Monumentos Nacionais do Norte, que lhe enviasse «o orçamento das obras necessárias no tecto da Biblioteca da Universidade de 
Coimbra».95 Em correspondência sucessiva, Gomes da Silva sublinhava «a urgência» com que a Repartição Central «deseja essa obra executada». ${ }^{96} \mathrm{O}$ orçamento foi enviado em fevereiro de 1932, apontando um montante de $19.910 \$ 00$ escudos ${ }^{97}$ A descrição pormenorizada dos gastos considerava as medidas exatas dos tetos e centrava-se na «reparação cuidadosa das pinturas dos painéis simbólicos e motivos decorativos dos tectos ${ }^{98}$, que cobriam uma superfície total de «540\$00 $\mathrm{m}^{2} »$, cujo custo por $\mathrm{m}^{2}$ era calculado em 25 escudos, num gasto total de «13.500\$00». ${ }^{99} \mathrm{O}$ orçamento é acompanhado pela seguinte «Memoria»:

[...] Comprehende a obra necessária para restaurar as pinturas dos painéis e das decorações, já muito damnificadas. Urgente é que se Ihes acuda. Tracta-se de um trabalho que demanda um cuidado extremo de execução; por este motivo o preço a prever não pode ser inferior ao que consta da série de preços respectiva, devendo também contar-se com a construção de um estrado desmontável, para facilidade de deslocação, porque os trabalhos a que fazemos referência, interessam trez salas. A importância total, orçada de harmonia com os preços dos jornais e dos materiais correntes naquela cidade, é de $19.910 \$ 00{ }^{100}$

O documento foi assinado pelo «arquiteto de $3^{\mathrm{a}}$ classe, Baltazar Silva Castro» e datado «Porto, 16 de Fevereiro de 1932».101 O orçamento «dos andaimes a fazer nas salas da Biblioteca da Universidade de

95 Sacavém, Instituto da Habitação e da Reabilitação Urbana [IHRU], Arquivo da ex-Direcção Geral dos Edifícios e Monumentos Nacionais, DREM Centro, caixa 2640, pasta 254, Universidade de Coimbra - Biblioteca, 1931-1934.

96 Ibidem.

97 Ibidem.

98 Ivi, caixa 2640, pasta 255.

99 Ibidem.

100 Ibidem

101 Ibidem 
Coimbra para pintar os tetos» foi apresentado alguns dias depois pelo «construtor civil diplomado António Simões Mizerela», tendo sido assinado pelo próprio em "Santo António dos Olivais, Coimbra». ${ }^{102}$ Em 30 de maio de 1932, Baltazar Silva Castro enviou a Gomes da Silva a seguinte comunicação:

Cumpre-me comunicar a V. Ex. ${ }^{a}$ que já estão feitos os andaimes [...]. Desejando levar comigo na próxima visita às obras um artista pintor do Porto para com ele determinar o mínimo de obra de reparação, venho rogar a V. Ex. ${ }^{a}$ a devida autorização. A obra de reparação e de consolidação das talhas, sanefas que se encontram em mau estado, já se encontram em andamento». ${ }^{103}$

O restauro visa conservar a originalidade da obra, limitando a intervenção de repintura.

Em 26 de junho de 1932, Joaquim Lopes «professor de pintura da Escola de Belas Artes do Porto, declara que se obriga à restauração de pintura de parte do tecto da primeira sala da Biblioteca de Coimbra, pela quantia total de 3.600\$00».104 Em setembro do mesmo ano Joaquim Lopes assina outro ajuste, declarando «que toma a seu encargo de proceder à restauração da pintura decorativa d'uma das salas da Biblioteca da Universidade de Coimbra pelo preço aproximado de $8.000 \$ 00$ escudos, sujeito a rectificação e servir de base para as restantes duas salas». ${ }^{105}$

Em novembro de 1932, outra «Memoria» dava conta do estado da pintura:

Encontra-se muito deteriorada, correndo risco de total desaparecimento [...] Impõe-se por tal motivo uma intervenção imediata á parte que

102 Ivi, caixa 2640, pasta 254

103 Ibidem

104 Ibidem

105 Ibidem 
resta indemne de estragos e os vestígios ainda aproveitáveis da que sofreu damnos, permitem o restauro da que está em via de desaparecimento. [...] É principal causa dos estragos a que nos referimos, o mau estado de conservação dos telhados. Urge substitui-los, realisando depois uma obra que assegura a boa vedação. Quanto aos tectos, será refeita toda a pintura damnificada, por pessoa de reconhecida competência. De obra análoga necessitam as estantes. A sua pintura decorativa também tem sido muito prejudicada pelo uso e pela acção do tempo. Não podem estes trabalhos levar-se a efeito sem a construção de uma prancha desmontável. ${ }^{106}$

O orçamento para a reforma dos telhados foi supervisionado pelo «agente técnico de engenharia contratado, Manuel Pinto» ${ }^{107} \mathrm{e}$ a Companhia Cerâmica das Devesas de Vila Nova de Gaia obrigou-se «ao fornecimento de telhas e capas romanas, para as obras de restauração dos tectos da Biblioteca da Universidade de Coimbra, postas sobre wagon [sic] na nossa Fabrica da Pampilhosa». ${ }^{108} \mathrm{Em}$ abril de 1933, começava-se o restauro da terceira sala, pois o «construtor civil António Simões Misarela, morador em Coimbra» assinou o orçamento para:

I - Montagem completa de andaimes de 4 pisos na $3^{a}$ sala por $3.500 \$ 00$ esc.

II - Asfaltamento de paredes salitradas, incluindo a picagem do reboco e gateamento a $30 \$ 00$ cada $\mathrm{m}^{2}$

III - Construção de sanefa de castanho molduradas a $100 \$ 00$ cada m$^{2}$

IV - Consolidação e reforço das linhas de tesoura e de estuque em castanho co-substituição de ferros, barrotame e fasquio carcomidos a $40 \$ 00$ cada $\mathrm{m}^{2}$.

106 Ivi, caixa 2640, pasta 256.

107 lbidem

108 Ibidem 
Declaro tomar toda a responsabilidade do seguro e assistência dos operários. $^{109}$

Baltazar Gomes da Silva enviou o orçamento de Miserela ao diretor geral Gomes da Silva, ressaltando: «Cumpre-me informar V. Exa que por se tratar de trabalhos delicados, os preços são aceitáveis julgando, portanto, a proposta merecedora da aprovação de V. Ex ${ }^{a} »{ }^{110} \mathrm{Em}$ outubro de 1933, o diretor da Biblioteca Geral da Universidade de Coimbra comunicou a Baltazar da Silva Castro o ter enviado «ao Ex.mo Senhor Comissário do Desemprego um oficio solicitando de S. Exa a cedência de dois turnos de cinco desempregados para procederem à limpeza das estantes desta Biblioteca - serviço este indispensável para se poder continuar a inteligente obra de restauração em que V. Ex ${ }^{\text {a }}$ tanto se tem empenhado»"111. Em outubro de 1933, outro ajuste assinado por Joaquim Lopes referiu o estado do restauro das pinturas, pois se obrigou ao:

I - Restauro completo da pintura dos tectos das duas ultimas salas da Biblioteca a $8.500 \$ 00$ ou seja por $17.00 \$ 00$.

11 - Restauro das pinturas das sancas e sanefas das referidas salas incluindo o douramento das três salas a $2.000 \$ 00$ ou seja por $6.000 \$ 00 .^{112}$

Em 10 de maio de 1934:

António Simões Mizarela declara que se compromete a concluir todos os trabalhos de carpinteiro da reparação das estantes, dos tectos, de todas as portadas, escadas repregamento geral incluindo a substituição

\footnotetext{
109 Ibidem

110 Ibidem

111 Ibidem

112 Ibidem
} 
de toda a talha corroída em castanho das sanefas, molduras, cimalhas das salas da Biblioteca da Universidade de Coimbra pela quantia total de $16.645 \$ 00$ esc. Mais declaro que neste preço está incluído todo o material, mão d'obra ferramentas e utensílios, ficando a meu cargo a responsabilidade do seguro de todo o pessoal operário. ${ }^{113}$

As obras incumbidas a Misarela estavam concluídas em junho de 1934. Em novembro, foi celebrado novo ajuste com outro construtor civil e «mestre de obras», o carpinteiro Manoel Ferreira Morango, morador no Porto:

... que de harmonia com os detalhes, condições, instruções dadas pela Direcção dos Monumentos Nacionais do Norte se obriga a concluir por tarefa de mão d'obra todos os trabalhos que faltam nas três salas da Biblioteca da Universidade de Coimbra incluindo tectos, sanefas, asfaltamento, telhado, rebocos, caleiras, etc. pela quantia de 20.000\$00. Mais declara que se obriga a fornecer todos os andaimes, ferramentas e a tomar a responsabilidade do seguro operário.114

Terminam com esta última anotação de despesa, os documentos relativos ao restauro que devolveu às pinturas de António Simões Ribeiro a feição atualmente visível. Na Biblioteca Geral da Universidade de Coimbra existem vários desenhos, traçados sobre lucidi ou com linhas picadas que, provavelmente, se referem ao restauro para serem copiados diretamente nas paredes e tetos [fig. 15]. 


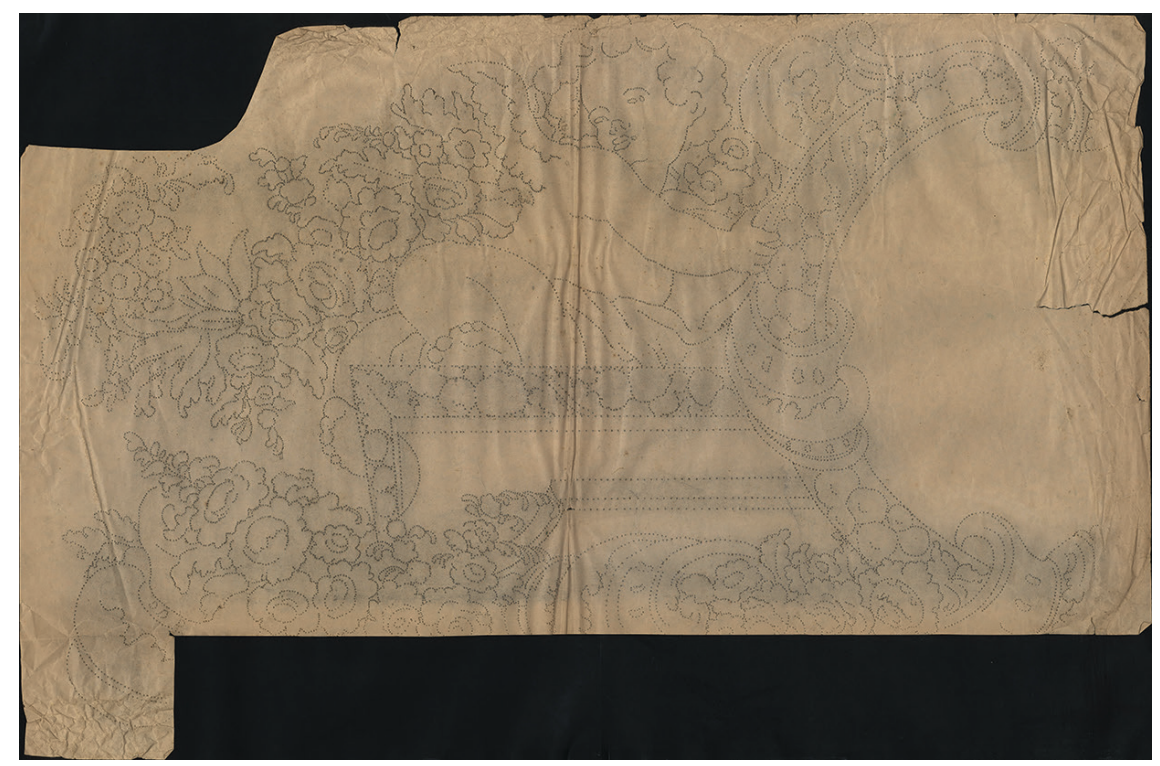

Fig. 15

Joaquim Lopes e ajudantes - Desenho para o restauro dos tetos da Biblioteca Joanina, Universidade de Coimbra

Podem ser também estudos académicos derivados dos trabalhos executados, que demonstram a fortuna artística das pinturas de António Simões Ribeiro e Vicente Nunes. ${ }^{115}$

\section{Conclusões}

Futuras investigações poderão assinalar pormenorizadamente os graus de conservação da pintura original, de integração das lacunas e de repintura integral. Seja como for, o restauro realizado entre 1931 e 1934 tinha por objetivo manter o programa iconográfico original, proporcionando a possibilidade atual de usufruir da única obra joanina concebida, realizada e concluída integralmente num arco de tempo relativamente breve se comparado com as outras empreitadas régias da época. Uma fotografia, datada de cerca de 1910 [fig. 6], ${ }^{116}$

115 Agradeço ao Diretor Adjunto da BGUC, Dr. Maia Amaral, que nos facultou as fotografias durante a minha pesquisa realizada em parceria com Vítor Murtinho.

116 Agradeço a Alexandre Ramires pela generosa partilha desta fotografia e pela datação baseada na análise técnica. 
testemunha o estado do teto da terceira sala, confirmando o respeito da iconografia original por parte do pintor Joaquim Lopes.

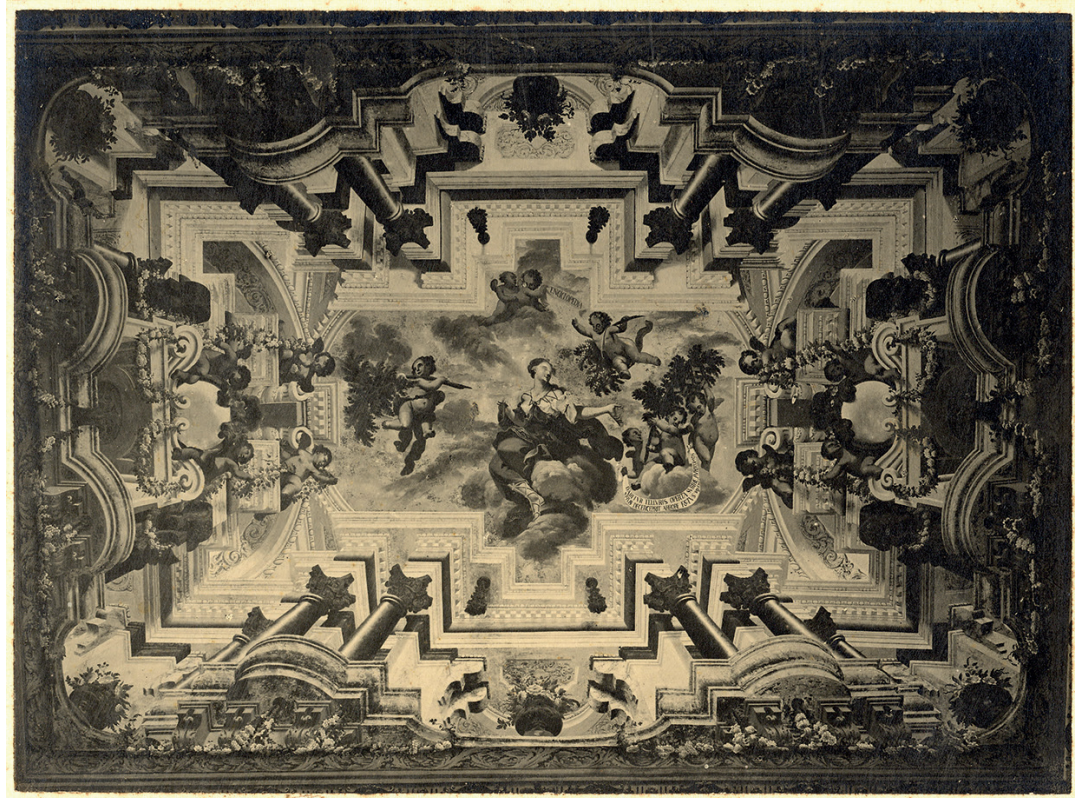

Fig. 16

José Maria dos Santos - Fotografia do teto da terceira sala, cerca de 1910. Foto de Alexandre Ramires

A obra levada a cabo pela Direção Geral dos Edifícios e Monumentos Nacionais integrou-se numa operação de valorização do património nacional que contrastava, nos seus fundamentos ideológicos, com o processo de abertura europeia e de renovação artístico-cultural e do conhecimento que motivara a construção e decoração da Biblioteca Joanina. A ligação entre Coimbra, capital do ensino universitário durante o antigo regime, e Lisboa, capital do reino e do império lusitano, expressava-se arquitetónica e simbolicamente no edifício erigido de 1717 até 1728, em plena harmonia com o contexto da "efervescência joanina" e a vontade régia de internacionalização das artes e dos artistas. 